\title{
Tuta absoluta (Meyrick) (Lepidoptera: Gelechiidae) on the "Offensive" in Africa: Prospects for Integrated Management Initiatives
}

\author{
Vimbai L. Tarusikirwa ${ }^{1}\left(\mathbb{D}\right.$, Honest Machekano ${ }^{1}$, Reyard Mutamiswa ${ }^{2}{ }^{\circledR}$, \\ Frank Chidawanyika ${ }^{2}$ (D) and Casper Nyamukondiwa ${ }^{1, * \mathbb{D}}$ \\ 1 Department of Biological Sciences and Biotechnology, Botswana International University of Science and \\ Technology, Palapye, Botswana; vimbai.tarusikirwa@studentmail.biust.ac.bw (V.L.T.); \\ machekanoh@biust.ac.bw (H.M.) \\ 2 Department of Zoology and Entomology, University of the Free State, P.O. Box 339, \\ Bloemfontein 9300, South Africa; 2018066841@ufs4life.ac.za (R.M.); ChidawanyikaF@ufs.ac.za (F.C.) \\ * Correspondence: nyamukondiwac@biust.ac.bw
}

Received: 13 August 2020; Accepted: 16 September 2020; Published: 6 November 2020

Simple Summary: The past decade has seen Africa being invaded by an invasive and destructive insect pest of tomato, the South American tomato pinworm. To date, the pest insect has since spread to almost the entire continent at lightning speed. Farmers have responded to this pest pressure through the sole injudicious use of chemical pesticides. However, this method of control is expensive, not effective (owing to reported insecticide resistance) and has potential adverse effects on the environment (including humans). To mitigate this, more environmentally friendly, bio-based and sustainable alternatives need to be put in place. Natural substances (NSs), for example, the use of pesticidal plant extracts, naturally occurring antagonists and related substances, can be used in this regard. A literature review was conducted explaining various factors that contributed to successful invasion by the pinworm. The review also explored various control mechanisms (e.g., biological control agents) that can be used in combination with natural and other low risk substances in a holistic way for successful pest control. Focus was also taken on the enabling and limiting factors that influence farmers in embracing the use of these NSs in an integrated approach.

\begin{abstract}
The South American tomato pinworm Tuta absoluta (Meyrick) has aggressively invaded the African continent. Since its first detection in North Africa in Morocco and Tunisia in 2008, it has successfully invaded the entire southern, eastern and western Africa, where it has been on the offensive, causing significant damage to Solanaceous food crops. While control of this prolific invader is primarily based on conventional synthetic pesticides, this form of control is consistently losing societal approval owing to (1) pesticide resistance development and consequential loss of field efficacy; (2) growing public health concerns; (3) environmental contamination and loss of biological diversity and its associated ecological services; and (4) unsustainable costs, particularly for resource-poor African farmers. As such, more ecologically sound pest management strategies, e.g., the use of natural substances (NSs), may offer a more sustainable approach to tackling this offensive. A systematic literature search through digital libraries and online databases (JSTOR, PubMed, Web of Science, SCOPUS and Google Scholar) was conducted using predetermined keywords on T. absoluta, e.g., South American tomato pinworm. We use this to explain the invasion of T. absoluta in Africa, citing mechanisms facilitating African invasion and exploring the potential of its control using diverse biological control agents, natural and low-risk substances. Specifically, we explore how botanicals, entomopathogens, semiochemicals, predators, parasitoids, host plant resistance, sterile insect technique and others have been spatially employed to control T. absoluta and discuss the potential of these control agents in African landscapes using more integrated approaches. We discuss the use of NSs as assets to general insect pest control, some potential associated liabilities
\end{abstract}


and explain the potential use and barriers to adoption in African systems from a legislative, economic, ecological and social standpoint.

Keywords: botanicals; invasive species; liabilities; pest management; tomato pinworm; natural substances

\section{Introduction}

Invasive insect pests are widely recognised as major threats to agricultural production, biodiversity conservation and the maintenance of ecological integrity [1-3]. Increased trade, human travel and globalisation have made crop production vulnerable to invasive alien insect pests [4-6]. In Africa, the rate of alien species invasion has dramatically increased in the past decades [7]. For example, "recent" invasive insect pest arrivals include Chilo partellus (Swinhoe) (Lepidoptera: Crambidae) [8], Prostephanus truncatus (Horn) (Coleoptera: Bostrichidae) [9], Phenacoccus manihoti Matile-Ferrero (Hemiptera: Pseudococcidae) [10], Bactrocera dorsalis (Hendel) (Diptera: Tephritidae) [11], Spodoptera frugiperda (JE Smith) (Lepidoptera: Noctuidae) [12] and indeed Tuta absoluta (Meyrick) (Lepidoptera: Gelechiidae) [13]. Given that $70-80 \%$ of African livelihoods depend on agriculture [14], these invasions represent a significant biosecurity as well as food and nutrition security threat.

Tuta absoluta, commonly known as the South American tomato pinworm, is one of the most invasive destructive insect pests of tomato (Solanum lycopersicum (Solanaceae)) globally $[13,15,16]$. It is thought to have originated from the Andes region in Peru before spreading to Latin American countries during the 1960s $[17,18]$. Although it is an endemic Neotropical insect pest whose initial distribution was restricted to its native range in South America, it has successfully extended its geographical range following an unintentional introduction in the Mediterranean basin $[15,19,20]$. It acquired global pest status after detection in eastern Spain in late 2006 [15,21], following introduction as a single initial Chilean population in the early 2000s [22]. Thereafter, it rapidly spread throughout Europe $[23,24]$. Since then, the pest has rapidly spread east- and southward, tracking favourable biophysical environments [16]. During the last 10 years, T. absoluta has also spread in the Middle East and Asia at lightning speed, resulting in extensive naturalised populations in India, Iran, Israel, Syria, Turkey and Nepal [25-29]. Following its invasion in most European countries, T. absoluta successfully invaded the Afrotropics, reportedly via the Mediterranean Sea, with first detections reported in Tunisia, Algeria and Morocco in 2008-2009 [15,25,30,31]. Since then, further detections have been reported in Niger, Nigeria (2010), Senegal (2012) [32], Sudan, Ethiopia (2011) [32], Kenya (2013) [33], Tanzania (2014) [34], Uganda (2015) [33], Zambia, Botswana, Mozambique, South Africa, Malawi (2016) [13,35-37] and Angola (2017) [13], thereby elevating its continental pest status. This rapid north-south and downward incursion between 2008 and 2017 poses a biosecurity threat to natural and agroecosystems in pest-free countries. On a global scale, this pest is believed to have increased from primarily infesting only $3 \%$ of the worldwide tomato cultivated areas to $60 \%$ within 10 years [16], with the most recent in China, a major tomato growing country [38].

Underlying the invasion success of T. absoluta is its superior climate adaptation [39], polyphagous nature [40-42] and high biotic potential [43,44]. In response to T. absoluta infestations, chemical control is often used as the first line of defence [18,45], providing a quick fix to pest pressure. It is relatively easy to apply, readily available and may be cost effective when applied at a large scale. However, synthetic insecticides are expensive to many resource-constrained sub-Saharan African (SSA) farmers. The endophytic behavioural feeding and cryptic nature of T. absoluta larvae render the widely used contact insecticides ineffective [46-48]. Moreover, synthetic insecticides also affect (i) non-target biological diversity and their related ecosystem services, e.g., natural enemies and pollinators, thus disrupting desirable trophic interactions; (ii) development of pest resurgence; (iii) insecticide resistance development; and (iv) public health, owing to residual insecticide contamination [3,49-52]. 
Some of these vices have already been observed in T. absoluta chemical control, e.g., insecticide resistance [53,54] and non-target effects on beneficial fauna [55]. The practical implications of the European Union Directive 2009/128/EC on the sustainable use of synthetic pesticides and the future prospects that residue restrictions may become more stringent also necessitate the exploration of novel, sustainable non-chemical alternatives for the management of T. absoluta [56]. As such, efficacious, ecologically sound and safer biologically based or natural alternatives are required for sustainable management of T. absoluta for use in an integrated approach. Natural insecticides/substances (NSs) are thus compatible as they are cost-effective and eco-friendly owing to their rapid environmental degradation $[57,58]$. However, studies on the NSs that are effective on T. absoluta are scattered in literature, warranting an in-depth comprehensive review of the current methods. This study, therefore, provides a comprehensive, gleaned compendium of potentially effective NSs on this invasive quarantine insect pest. The understanding of the role and potential of NSs in limiting $T$. absoluta economic damage is important in establishing a baseline for sustainable management options. NSs widely used in pest management include microbial (e.g., entomopathogens and entomopathogenic nematodes), botanical (e.g., insecticidal plants or their derivatives) and semiochemical agents [59-63]. Despite availability of multiple potential options, current organic tomato production systems mostly rely on Saccharopolyspora spinosa (spinosad), Azadirachta indica (neem) and Bacillus thuringiensis toxins [16,64], signifying underutilisation of NSs. Moreover, identification and screening of effective locally available NSs remain scant in Africa $[63,65,66]$. Although NSs are environmentally friendly and have shown to be very effective in pest control, they have not been widely adopted by African farmers. Thus, this review also discusses T. absoluta invasion in Africa, possible mechanisms of invasion and the prospects of incorporating natural and low risk substances as assets in an integrated management approach. We also discuss barriers to the adoption and use of NSs in African agricultural systems from a legislative, economic, ecological and social standpoint.

\section{Economic Impact of Tuta absoluta in Africa}

Tomatoes are an important component of horticulture and a major pillar of sustainable development, with significant contribution to household and national food and nutritional security $[42,67]$. They are a cash crop grown for home consumption in the backyards of the majority homesteads across SSA and are an important source of vitamins [68]. Tomato production also significantly contributes to economic development ascribed to its high economic returns and ability to create employment ( $\sim 60 \%$ of total labour force) and along the value chain [69,70]. About 170 million tonnes of tomatoes are produced worldwide [16,71]. Of this figure, Africa accounts for $\sim 37.8$ million tonnes annually. However, this figure is threatened by increased T. absoluta damage [29], with downstream consequences on African socio-economic value chains and household livelihoods [72].

Tuta absoluta larvae attack almost all aerial parts of tomato plants, resulting in $\sim 80-100 \%$ yield losses if left uncontrolled [73]. Larval feeding also reduces fruit quality through creating pin holes prone to secondary attack by pathogens, rendering them unmarketable [74]. Increased cost of production has been reportedly experienced by small- and large-scale farmers in Africa due to increased costs for pesticides [62]. For example, recent evidence suggests decreased tomato yields and increased production costs [72]. Highest losses are mostly experienced during early invasion owing to inadequate mitigation measures related to lack of preparedness [18]. Nigeria experienced up to $80 \%$ losses in tomato produce in 2016 due to unfamiliarity with the pest and management strategies [70]. This reduced supply and catapulted an estimated 10-fold increase in tomato prices due to the laws of demand and supply [75]. Similarly, following T. absoluta invasion in South Africa (2016), pest-free countries banned importation of tomato and other Solanaceae crops from that country [13], resulting in significant economic losses. Similar losses have also been reported in Southwestern Angola [76]. Thus, T. absoluta pest pressure has negatively affected agricultural enterprises in Africa through direct losses and increased costs in pest management [29]. Tuta absoluta remains a pest of quarantine importance in countries under the Inter-African Phytosanitary Council (IAPSC) and has been reported on the 
European and Mediterranean Plant Protection Organization's (EPPO's) A2 list as a regulated insect pest [77].

\section{Tuta absoluta Invasion Pathways and Distribution in Africa}

Long-distance transmission and short-distance dispersal are the key drivers of T. absoluta invasion [78]. International agricultural trade is a key long-distance transmission mode that may have contributed to a larger extent in the introduction of T. absoluta into Africa, e.g., importation of fruits (e.g., tomatoes and egg plants) from pest-infested areas $[29,79]$. Other possible pathways for long-distance dissemination include production facilities and packaging materials (e.g., boxes, crates and pallets) from infested countries $[43,80]$. Hence, production facilities repack and distribute infested fruits, resulting in long-distance dissemination, reviewed in [81]. In addition, propagule material (e.g., seedlings), farm equipment and transportation vehicles from pest-infested areas are also possible pathways for long-distance transmission [78,79,82]. From the foregoing, the rapid spread across Africa may have been exacerbated by porous port of entries, weak phytosanitary regulations and ineffective early surveillance in the region [18]. Furthermore, natural factors (e.g., wind and water), larval crawling and adult flight are possible key short-distance dispersal pathways [78]. To date, T. absoluta has been reported in 41 of the 54 African countries (see [29]). The pest has not yet been officially reported in a few central and southwestern African countries [13,16]. However, cognisance of the widespread presence in Africa, this absence may be a consequence of lack of surveillance and pest detection mechanisms.

\section{Factors Supporting T. absoluta Invasion in Africa}

\subsection{African Environments and Tuta absoluta Niche}

Interactions between the invader and the recipient agro-ecological regions influence pest establishment and spread, with the prevailing biophysical environment contributing to the invasion process $[24,83,84]$. Tropical regions, such as the majority of Africa, are highly vulnerable to insect pest invasions $[24,85,86]$. Among the key determinants of invasion success are climatic suitability, propagule pressure and the availability of suitable hosts [87,88]. Environmental matches between native and novel invasion areas play a pivotal role in invasion success [89]. Modelling studies have shown that temperature, relative humidity (RH) and hosts are critical determinants of T. absoluta successful invasion $[24,43,90]$. Research shows that Africa is a suitable biophysical niche for the pest $[24,42,43]$. Various models have been constructed to predict environmental suitability, potential and timing of T. absoluta spread in Africa $[24,43,90]$. Indeed, these models suggest temperature and RH environments for Africa are ideal for T. absoluta invasion and population establishment. However, it appears RH seems to have the strongest influence in T. absoluta invasion [24]. A comparison of temperature and precipitation between its native range and invaded African region shows a similarity in temperature ranges. However, the native range experiences higher precipitation as compared to the areas invaded in Africa (Figure 1). Nevertheless, reports suggest T. absoluta can thrive in high temperature and low precipitation environments as long as host plants are available [43]. The optimal temperature for its development is $30^{\circ} \mathrm{C}$, with egg, larval and pupal lower developmental thresholds at $6.9,7.6$ and $9.2^{\circ} \mathrm{C}$, respectively [91,92]. In addition, the upper developmental threshold from the egg to adult cycle is $37.3^{\circ} \mathrm{C}$ [93]. Low temperature and high altitudes $(>1000 \mathrm{~m})$ are limiting factors for its survival, and a high RH is suitable for its development and life span $[43,94,95]$. The negative impact of rainfall on population abundance of T. absoluta has been reported [96]. Based on these ecological requirements and evidence presented in Machekano et al. [42], warm and humid conditions prevalent in Africa potentially elucidate its invasion success. 


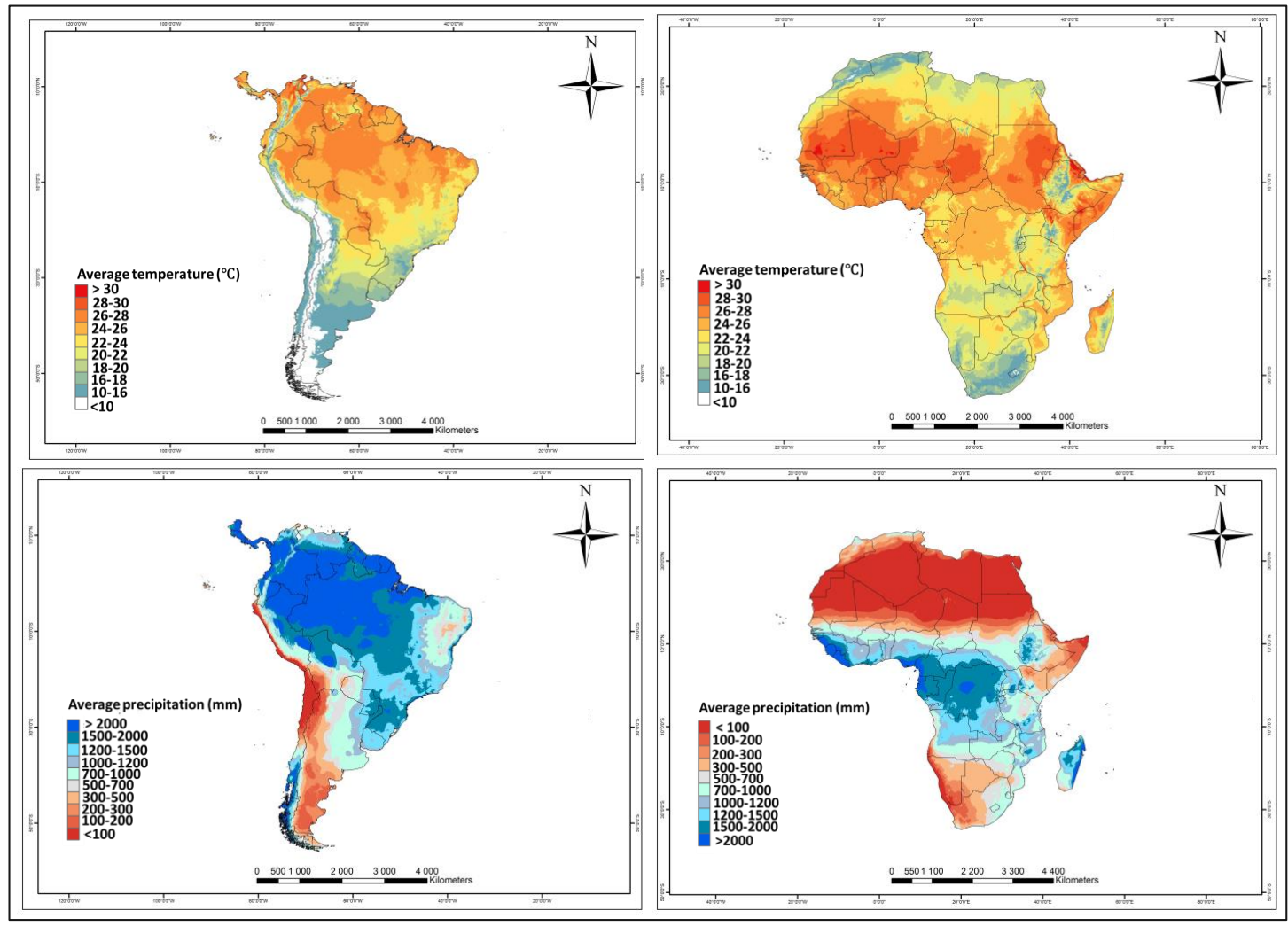

Figure 1. Temperature and precipitation comparison between the T. absoluta native (South America) and invaded (Africa) regions. The maps generally show that the T. absoluta niche is largely similar between the native and invaded region and thus successful establishment is possible. Maps were drawn in ArcGIS 10.3 from ESRI with data obtained from WorldClim Ver 2.0.

\subsection{Physiological Tolerance}

Environmental adaptations enable invasive species to overcome variable stressful barriers along the invasion continuum and significantly contribute to alien species propensity [97-99]. Overcoming different stressful environmental barriers is the first of several potential factors determining whether a species may become established, naturalised and ultimately invasive [83]. Temperature is the key abiotic "ecological filter" [100] for successful invasion in novel habitats [101]. As such, failure to mount any compensatory physiological resistance mechanisms against environmental barriers may offset invasion success $[42,102]$. Physiologically, some insect pests often increase invasion success through employing either increased phenotypic plasticity or basal stress tolerance $[39,98,99,103]$. A previous study has shown that $T$. absoluta larvae are more thermally plastic than adults and can shift their thermal tolerance in short and long timescales [39]. In addition, larvae showed a higher basal heat tolerance than adults, whereas adults recorded superior basal cold tolerance relative to larvae $[42,104]$. This physiological tolerance may help elucidate the notion that ecophysiology may have aided the current invasion by T. absoluta.

\subsection{Increased Number of Generations}

Tuta absoluta is an r-selected, multivoltine species [105] that remains active in Mediterranean and African winter climates [104,106,107]. Its pest status is largely associated with a high rate of reproduction, with each female producing up to 260 eggs during its lifetime [108]. Under the projected warming in Africa [109], this promotes an even shorter developmental time and higher voltinism. The life cycle of T. absoluta takes $\sim 24-38$ days at $27^{\circ} \mathrm{C}$, resulting in $\sim 10$ to 13 generations per 
year $[15,16,91,106]$. This rapid development may give T. absoluta a numerical advantage and propagule material that facilitates species proliferation.

\subsection{New Niche with Limited Natural Enemies}

The enemy release hypothesis postulates that invasive species likely have reduced biotic pressure (e.g., natural enemies) than their native counterparts [110]. It also follows that parasitoids and predators (see $[111,112]$ ) specific to the invasive species may be absent in the novel areas, resulting in the pest not being suppressed [113] owing to a lack of co-evolved biological control agents following invasion [114]. This is likely the reason behind the limited natural biotic pressure on T. absoluta in Africa, consequently contributing to its quick establishment [72]. The enemy-free hypothesis also states that invading species often perform better and experience rapid population growth in new areas [115-117]. This is because in the new habitats, invading species may at most encounter opportunistic generalist natural enemies in their new range, but not more efficacious coevolved specialists [113,116-118]. Indeed, various indigenous generalist predators and parasitoids have been recorded as potential biological agents of T. absoluta in some parts of Africa, albeit with low efficacy [13]. However, these studies remain scant and constrained in space [72]. Various authors have reviewed the natural enemy complex of T. absoluta $[15,16,119,120]$. Amongst these species, a few have been recorded in Africa. The few documented in the continent are mostly prevalent in North Africa [13]. The generalist mirid predator Nesidiocoris tenuis (Reuter) (Hemiptera: Miridae) has been the most reported, albeit also confined to North Africa [13,121]. Other predators recorded include Macrolophus pygmaeus, (Rambur) (Hemiptera: Miridae), Macrolophus caliginosus (Wagner) (Heteroptera: Miridae), Dicyphus tamaninii (Wagner) (Heteroptera: Miridae), Rhynocoris segmentarius (Germar) (Hemiptera: Reduvidae) and Dicyphus errans (Wolff) (Hemiptera: Miridae) [13]. In Africa, the parasitoid complex that has so far been recorded through field monitoring and surveys include larval braconid parasitoids of the genus Apanteles and Bracon in Nigeria; egg parasitoids of the genus Trichogramma in Nigeria, Tunisia, Algeria and Morocco [13,122]; and several hymenopterous parasitoid species belonging to different families (Kenya), including B. nigricans, B. hebetor, Dolichogenidea appellatory (Telenga) (Hymenoptera: Braconidae), Ecdamua cadenat (Risbec) (Hymenoptera: Torymidae) and Neochrysocharis formosa (Westwood) (Hymenoptera: Eulophidae) in Sudan [13]. However, reports suggest these parasitoids cannot solely provide effective T. absoluta control [13]. Thus, use of other complementary NSs combined in an integrated approach may improve efficacy and sustainability in T. absoluta management (Figure 2). To our knowledge, no egg parasitoids have been recorded in southern Africa. Thus, the inefficiency by current spatially isolated indigenous natural enemies coupled with total absence in some regions [13] has provided an enemy-free platform for T. absoluta successful invasion and establishment. 


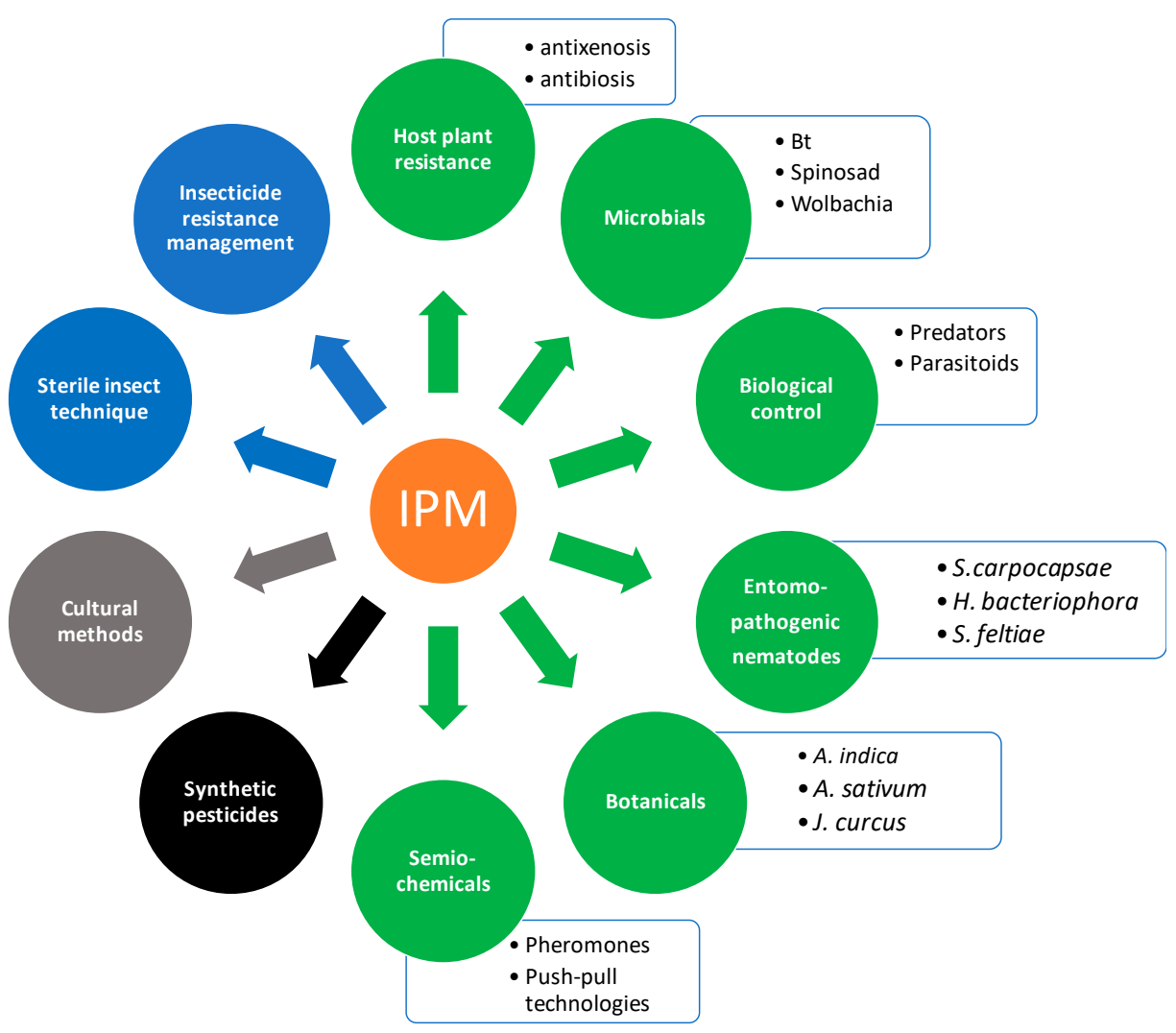

Figure 2. Schematic representation of proposed integrated pest management programme for Tuta absoluta. The emphasis is on the use of NSs, low-risk substances and biological control agents (green). Classic examples of "agents" or model organisms used within each category are given. A holistic use, in a judicious combination with target specific pesticides (black), environmentally friendly and low risk techniques (blue) and good crop management, (grey) may help in the IPM of this pest insect. These methods should be used in the presence of sound legislative measures that promote integrated approaches to pest management. Note, these examples are not purely exhaustive, but provide baseline information for IPM.

\subsection{Wide Host Range}

Tuta absoluta is polyphagous, exploiting a wide range of alternate hosts $[123,124]$. This behaviour allows the continuous and spatial omnipresence of the pest. Although Özgökçe et al. [41] reported 26 different host plant species for T. absoluta, it has a strong preference for solanaceous species, with tomato, potato (Solanum tuberosum) and European black nightshade (Solanum nigrum) being the most preferred $[15,125]$. In addition, it can also oviposit and develop on several plants belonging to the Amaranthaceae, Convolvulaceae, Fabaceae and Malvaceae [16]. Since T. absoluta is rapidly and continually evolving, evidence suggest it is also expanding its host range [124]. For example, in Sudan, T. absoluta was recorded on watermelon (Citrullus lanatus) and alfalfa (Medigo sativa) [40] and on weeds such as thorn apple Datura stramonium [124]. In Algeria, Drouai et al. [126] found T. absoluta on beet (Beta vulgaris), spinach (Spinacia oleracea) as well as the weed species Chenopodium bonushenricus and C. rubrum. In South Sudan up to 50\% of the T. absoluta damage was observed on potato foliage [30]. In Botswana, T. absoluta was spotted on some wild hosts, Solanum aculeatissimum (Jacq.), Solanum coccineum (Jacq.) and Solanum supinum [42]. Apart from the main solanaceous plant hosts, T. absoluta affects other crops of economic importance (Table 1). The availability of alternative host plants is an important factor that allows the sustainability of the pest in the absence of the primary tomato host $[42,127]$. Therefore, the presence of a wide range of both cultivated and wild host plants in African landscapes creates a refuge opportunity for host switching and consequent pest success. 
Table 1. Alternative host plants of Tuta absoluta reported in the literature. The list may not be purely exhaustive but was compiled using the literature available at the time of writing.

\begin{tabular}{|c|c|c|}
\hline Family & Host Plant & Reference \\
\hline \multirow[t]{37}{*}{ Solanaceae } & Solanum tuberosum L. & [15] \\
\hline & Solanum nigrum L. & [125] \\
\hline & Solanum melongena L. & [128] \\
\hline & Solanum aethiopicum $\mathrm{L}$. & [96] \\
\hline & Solanum anguivi Lam. & [82] \\
\hline & Solanum macrocarpon $\mathrm{L}$. & [82] \\
\hline & Solanum scabrum Mill. & [82] \\
\hline & Solanum villosum Mill. & [82] \\
\hline & Solanum aculeatissimum (Jacq.) & [42] \\
\hline & Solanum coccineum (Jacq.) & [42] \\
\hline & Solanum supinum Dunal & [42] \\
\hline & Solanum americanum Mill. & [128] \\
\hline & Solanum bonariense L. & [129] \\
\hline & Solanum elaeagnifolium Cav. & [129] \\
\hline & Solanum gracilius Herter & [129] \\
\hline & Solanum hirtum Vahl & [130] \\
\hline & Solanum pseudo-capsicum L. & [129] \\
\hline & Solanum sisymbrifolium Lamb & [129] \\
\hline & Solanum dulcamara Linnaeus & {$[48]$} \\
\hline & Solanum lyratum Thunb. & [131] \\
\hline & Solanum puberulum Nuttal ex Seemann & [131] \\
\hline & Nicotiana longiflora Cav. & [124] \\
\hline & Nicotiana tabacum L. & [15] \\
\hline & Nicotiana rustica L. & [48] \\
\hline & Nicotiana glauca (Graham) & [82] \\
\hline & Datura stramonium L. & [124] \\
\hline & Datura quercifolia Kunth & [128] \\
\hline & Datura ferox $\mathrm{L}$. & [132] \\
\hline & Xanthium brasilicum Vell. & [124] \\
\hline & Capsicum annum L. & [41] \\
\hline & Capsicum frutescens L. & [96] \\
\hline & Nicandra physalodes (L.) Gaertner & [48] \\
\hline & Lycium halimifolium Mill. & [48] \\
\hline & Lycium chilense (Coralillo) & [131] \\
\hline & Lycium hirsutum L. & [82] \\
\hline & Physalis peruviana $\mathrm{L}$. & [133] \\
\hline & Physalis angulata $\mathrm{L}$. & [130] \\
\hline \multirow[t]{7}{*}{ Amaranthaceae } & Amaranthus spinosus L. & [124] \\
\hline & Amaranthus viridis L. & [78] \\
\hline & Spinacia oleracea L. & [126] \\
\hline & Beta vulgaris vulgaris $\mathrm{L}$. & {$[126,134]$} \\
\hline & Chenopodium bonus-henricus (L.) Rchb. & [126] \\
\hline & $\begin{array}{c}\text { Chenopodium rubrum (L.) S. Fuentes, } \\
\text { Uotila \& Borsch }\end{array}$ & [126] \\
\hline & Chenopodium album $\mathrm{L}$. & [134] \\
\hline \multirow[t]{3}{*}{ Fabaceae } & Phaseolus vulgaris L. & [135] \\
\hline & Medicago sativa $\mathrm{L}$. & [124] \\
\hline & Vicia faba L. & [124] \\
\hline Cucurbitaceae & $\begin{array}{c}\text { Citrullus lanatus (Thunb.) Matsum. \& } \\
\text { Nakai }\end{array}$ & [124] \\
\hline \multirow[t]{2}{*}{ Convolvulaceae } & Convolvulus arvensis L. & [134] \\
\hline & Calystegia sepium (L.) Brown & [134] \\
\hline Malvaceae & Malva sylvestris L. & {$[48]$} \\
\hline \multirow[t]{2}{*}{ Asteraceae } & Sonchus oleraceus L. & [78] \\
\hline & Xanthium strumarium L. & [136] \\
\hline Poaceae & Sorghum halepense (L.) Pers. & [78] \\
\hline Brassicaceae & Sinapis arvensis L. & [136] \\
\hline
\end{tabular}




\subsection{Pesticide Resistance}

Synthetic insecticides are employed as the primary method of control against insect pest infestation [2,137]. For example, Tunisia registered 18 new insecticides during 2009-2011 following T. absoluta invasion although they all turned out ineffective $[25,138]$. Intensive use of synthetic insecticides for $T$. absoluta management coupled with insect biological traits, such as a high reproductive potential and multivoltinism, endophytic larval feeding behaviour and mining habit as well as polyphagy, has increased T. absoluta selection pressure for insecticide resistance [53,139,140]. In South America and Europe, resistance has been reported against conventional insecticides such as organophosphates (OPs), pyrethroids, cartap, diamides and avermectins [16,46,139,141,142]. The main resistance mechanisms evolved through altered target-site sensitivity and/or enhanced detoxification, depending on the chemical class [64]. In northern Nigeria, resistance was reported in cyhalothrin (a Type II pyrethroid), propoxur and chlorpyrifos-methyl via enzyme mutation, underlying the challenges in managing this invasive pest using pesticides [70]. Given the prohibitive costs of synthetic pesticides for African farmers, evolution of pesticide resistance will further compound losses on already resource-constrained farmers.

\section{Potential Use of Natural Substances}

\subsection{Botanicals}

Botanical insecticides are naturally occurring chemicals extracted from plants with insecticidal properties $[61,143]$. They can be classified based on their chemical constituents into categories, namely, essential oils, flavonoids, alkaloids, glycosides, esters and fatty acids [144-148]. Plant derivatives and bioactive compounds have been used to manage different crop pests with notable success [63]. Their physiological effects on insects vary depending on the target site and mode of action [61], with most acting as repellents, feeding deterrents/antifeedants, toxicants, growth retardants, chemosterilants and attractants $[61,63,149]$. Plant parts used are dependent on the targeted bioactive compounds as well as their localised concentrations. However, use of barks, leaves, roots, flowers, seeds and stems is widely reported [63]. Common botanicals with reported insecticidal properties include neem (A. indica), garlic (Allium sativum), ginger (Zingiber officinale) and pyrethrum (Tanacetum cinerariifolium) [63,143].

Given the wide availability of botanicals, ease of application and low operational costs, botanicals are a viable option for sustainable T. absoluta management. Azadirachta indica and Jatropha curcas extracts have been reported as efficacious on T. absoluta eggs and larvae [150]. In an empirical study, four-day exposure to J. caurcas and A. indica seed extracts resulted in $18 \%$ and $25 \%$ egg mortalities, respectively, whilst 24-h treatment elicited larval mortalities ranging from 23.5 to $48.5 \%$ and 33 to 46.7\%, respectively. In another study, Abdel-baky and Al-Soqueer [151] showed that simmondsin extracts, obtained from seeds of Jojoba, Simmondsia chinensis L., were effective in controlling 2nd instar larvae of T. absoluta. Field studies showed 71.82 and $74.26 \%$ larval mortalities following treatment using the biopesticides $A$. sativum and A. indica, respectively [152]. Furthermore, ethanolic leaf extracts of Piper amalago var. medium, P. glabratum and P. mikanianum significantly elicited T. absoluta larval mortalities [153]. Piper species have amides (e.g., piperamides) that are known to have neurotoxic and lipid metabolism effects [154], manifesting as knockdown and paralysis followed by death [155]. Several other plant extracts have been found to be effective against T. absoluta (Table 2). Given the efficacy of some of the reported botanicals, e.g., [151] (Table 2), using them in combination with soft pesticides and in an integrated approach could provide more optimised control. However, despite empirical support for the botanicals' efficacy, their use in agriculture is currently limited in commercial use on vegetable and fruit crops with few prospects for commercial development of new products [143]. Several factors affect the wide success of botanicals as conventional pesticides; for example, availability of plant material, solvent types, rapid environmental degradation, registration bureaucracy, market opportunities and availability of competing products are some of the barriers to successful use of botanical insecticides [143]. 
Table 2. Insecticidal plants used to make botanicals used against Tuta absoluta (Eggs—E; Larvae-L; Pupa-P; Adults-A). The records were obtained from the literature at the time of writing and may not be purely exhaustive.

\begin{tabular}{cccc}
\hline Natural Substance & Species & Host Developmental Stage & Reference \\
\hline Botanicals & Azadirachtin spp. & E, L, P & {$[150]$} \\
& Petroleum ether extract & E, L & {$[150]$} \\
Jatropha curcus & E, L & {$[150]$} \\
Allium sativum & L & {$[156,157]$} \\
Ocimum basilicum & L & {$[156,157]$} \\
Thymus vulgaris & L & {$[156,157]$} \\
Ricinus communis & L & {$[156,157]$} \\
Eucalyptus spp. & L & {$[156,157]$} \\
Melia azedarach & L & {$[156,157]$} \\
Geranium spp. & L & {$[156,157]$} \\
Allium cepa & L & {$[156,157]$} \\
Citrus aurantium & L & {$[158]$} \\
Piper amalago var. & L & {$[153]$} \\
medium & L & {$[153]$} \\
Piper glabratum & L & {$[153]$} \\
Piper mikanianum & L & {$[151]$} \\
\hline
\end{tabular}

\subsection{Entomopathogens}

Entomopathogens, such as Metarhizium anisopliae var. anisopliae (Metsch.) Soroki, Beauveria bassiana (Balsamo) Vuillemin and Bacillus thuringiensis (Berliner) have shown efficacy against T. absoluta (Table 3) [159,160]. The soil dwelling bacterium B. thuringiensis is one of the most important microorganisms with entomopathogenic properties [161]. It is environmentally friendly and can be extensively used as part of an integrated approach to pest management [81]. Apart from Lepidoptera, $B$. thuringiensis was reported to exhibit insecticidal effects on many other insect orders [161], making it ideal for sustainable integrated management. Indeed, both B. bassiana and B. thuringiensis have been used to control an array of pest insects, including whiteflies, thrips and termites [162,163]. Bacillus thuringiensis has already been widely used in T. absoluta control [160,161]. Efficacy studies of B. bassiana and B. thuringiensis on T. absoluta showed that third instar larvae were most susceptible [60]. Furthermore, their interaction effects were synergistic in T. absoluta control. By contrast, Gonzalez-Cabrera et al. [160] found evidence that first instar larvae were the most susceptible to $B$. thuringiensis and that it could keep T. absoluta below economic thresholds [164]. Similarly, Biondi et al. [16], reported that Wolbachia bacterial infection may potentially be efficacious for T. absoluta through its effects on reproduction. Spinosad, a fermentation product of S. spinosa, has also been used in T. absoluta control [165-167]. However, its continued use has been threatened by resistance [168]. Thus, there is need for complementary control options to fight T. absoluta, if pest populations are to be maintained below economic threshold levels [16]. Regardless of sporadic resistance reports for these substances, they still remain reliable and efficacious sustainable options to pest control in integrated systems. 
Table 3. Microbials and other natural substances used as biopesticides against Tuta absoluta. (Eggs-E; Larvae-L; Pupa-P; Adults-A). The records were obtained from the literature at the time of writing and may not be purely exhaustive.

\begin{tabular}{cccc}
\hline Type of Microbial & Species & Host & Reference \\
\hline \multirow{2}{*}{ Entomopathogens } & Bacillus thuringiensis & $\mathrm{L}$ & {$[160,169]$} \\
& Bacillus thuringiensis kurstaki & $\mathrm{L}$ & {$[169]$} \\
& Beauveria bassiana & $\mathrm{L}$ & {$[169]$} \\
& Metarhizium beauveria & $\mathrm{L}$ & {$[170]$} \\
& Metarhizium anisopliae & $\mathrm{L}$ & {$[170]$} \\
& Baculoviruses (NPVs) & $\mathrm{L}$ & {$[171]$} \\
Entomopathogenic nematodes & Saccharopolyspora spinosa & $\mathrm{L}$ & {$[172]$} \\
& Steinernema affine & $\mathrm{L}$ & {$[172]$} \\
& Steinernema carpocapsae & $\mathrm{L}$ & {$[172]$} \\
& Steinernema feltiae & $\mathrm{L}$ & {$[62]$} \\
& Heterorhabditis bacteriophora & $\mathrm{L}$ & {$[62]$} \\
& Pheromones & $\mathrm{A}$ & {$[36,59]$} \\
& Antimicrobial peptides (AMPs) & $\mathrm{E}, \mathrm{L}, \mathrm{P}$ & {$[173]$} \\
\hline
\end{tabular}

\subsection{Entomopathogenic Nematodes (EPNs)}

Entomopathogenic nematodes (EPNs) (Table 3) are biological control agents that can kill insect pests using their coevolved mutualistic intestinal bacterium [174-176]. Their use in pest management is already widespread and have shown efficacy in diverse taxa [177]. Entomopathogenic nematodes have been used against similar Lepidopterans, e.g., false codling moth (Thaumatotibia leucotreta), codling moth (Cydia pomonella) and the sugarcane borer (Eldana saccharina) $[176,178,179]$. Recent studies have shown the EPNs Steinernema feltiae, S. carpocapsae and Heterorhabditis bacteriophora are effective against all larval instars of T. absoluta (Table 3) [177]. Similarly, Kamali et al. [62] reported high efficacy for S. carpocapsae and H. bacteriophora against fourth instar larvae. These results suggest scope for EPNs in T. absoluta management and can be an intergap component of an integrated management approach.

\subsection{Semiochemicals}

Semiochemicals are chemicals mediating interactions across organisms by eliciting behavioural responses in recipient organisms within and across species. Sex pheromones have been, by far, the most widely used semiochemicals in pest management [59]. Semiochemical-based management of insects usually include pheromone lure and kill, mass trapping and disruption of mating activities $[47,180]$. Pheromones can also be effectively utilised in population monitoring to determine action thresholds, early pest detection and other manipulations of insect pest behaviour [181]. This form of control has been successfully implemented in South America, Europe, Asia and Africa in managing T. absoluta in greenhouses and open fields [42,81]. Using sex pheromones, Filho et al. [182] recorded 233 males/trap/day under greenhouse conditions. These trap catches can be used as part of a mass trapping T. absoluta control strategy. Pheromone-mediated control of T. absoluta is more recommended as a supplementary measure in combination with other management options. For example, a study in Egypt showed that a combined use of sex pheromone and other insecticides is effective against T. absoluta larvae [183]. Similarly, Cherif et al. [184] showed that mass trapping in combination with B. thuringiensis and cyromazin significantly reduced T. absoluta numbers. Other behaviour-modifying strategies, e.g., the push-pull strategies, have worked successfully for the management of other Lepidopteran pest insects [185]. However, to our knowledge, empirical studies showing the efficacy of a push-pull strategy in T. absoluta control in Africa is missing. Moreover, the use of a pheromone-mediated management system in Africa is also low due to high costs and limited availability. Nevertheless, semiochemicals represent an efficacious and sustainable approach to pest management. 


\subsection{Sterile Insect Technique (SIT)}

Sterile insect technique is an environmentally friendly control option aiming to suppress pest populations through $\mathrm{F}_{1}$ generation sterility enabled by release of sterile males that mate with wild females [186], thereby producing non-viable offspring [186-188]. However, male sterilisation can reduce fitness thereby compromising field competitiveness [189]. As such, various mechanisms have been put in place to compensate for this reduced fitness and maintain optimal SIT efficacy in the field, including the use of low dosage gamma radiation and thermal preconditioning/acclimation [186,190].

Sterile insect technique has been used successfully for control of Lepidopterans, e.g., pink bollworm, Pectinophora gossypiella (Saunders) (Lepidoptera: Gelechiidae) [191]; false codling moth, T. leucotreta (Lepidoptera: Tortricidae) [192]; and codling moth, C. pomonella (Lepidoptera: Tortricidae) [193]. The technique can be used in an area-wide management approach, incorporating other options such as natural enemies, cultural control and the application of bio-rational pesticides [194,195]. Cagnotti et al. [191] reported that the inherited sterility control of T. absoluta can be combined with the use of the predator Tupiocoris cucurbitaceus in pest management. Given the efficacy of SIT in pest management, its environmental soundness coupled with a high compatibility with other control measures, SIT warrants exploration for use in T. absoluta management in Africa.

\subsection{Host Plant Resistance}

Development of tomato cultivars resistant to pests is an important strategy in pest control using NSs and is one of the fundamental pillars of an integrated management approach [196]. While few moderately resistant tomato cultivars have been reported [197,198], the majority are highly susceptible to T. absoluta infestation. Three mechanisms may account for plant resistance to insect attack, namely antixenosis, antibiosis and tolerance [199]. Thus, tomato cultivars significantly differ in their susceptibility to T. absoluta [200-203], and that resistance is positively associated with trichomes density and the diversity and concentrations of host secondary metabolites [201,202,204]. Indeed, tomato plants possess glandular trichomes that produce volatile and non-volatile secondary metabolites, e.g., acyl sugars, terpenoids, phenylpropanoids, flavonoids and phenolic compounds [200,205]. Therefore, breeding programmes have targeted lines with high acyl sugars and other secondary metabolites, e.g., zingiberene for host resistance against pests in tomato production $[16,136]$. Use of resistant varieties may also offer a cost effective and sustainable approach to the fight against the T. absoluta scourge in Africa.

\subsection{Use of Predators and Parasitoids}

Several predators and parasitoid biological control agents have been demonstrated to suppress populations of the tomato pinworm below economic threshold levels (Table 4). Conservation and augmentative biological control programmes using predators and parasitoids have been developed for T. absoluta following its invasion in Europe [16] and Africa [31,119,206,207]. Hemipteran predators, notably anthocorids, geocorids, mirids, nabids and pentatomids, have been identified as T. absoluta biocontrol agents in both native and invaded areas [15,16]. The generalist predators M. pygmaeus, N. tenuis and Dicyphus spp. [208] are the most common antagonists in European greenhouses [119]. Their use has been complemented with B. thuringiensis sprays against the early larval infestations [209]. Adults and nymphs of M. pygmaeus and N. tenuis prey on T. absoluta eggs and larvae (preferably first instar) [206,210]. Dicyphus tamaninii has been reported as a predator of T. absoluta eggs and larvae in North Africa [206]. Other predators reported in Africa include N. tenuis, M. pygmaeus, M. caliginosus, D. tamaninii, R. segmentarius and D. errans [13]. In Spain, predatory lacewings (Chrysoperla carnea) and mites (Amblyseius swirskii Athias-Henriot and A. cucumeris Oudemans) have been reported as egg and larval biocontrol agents. Furthermore, predatory ants, e.g., Tapinoma nigerrimum (Nylander) has been identified as a biocontrol agent in North Africa (Table 4). Where available, conservation of 
these predators as NSs or mass rearing for use as augmentation or inoculative releases may offer a sustainable approach to the management of T. absoluta.

Hymenopteran egg parasitoids belonging to the genus Trichogramma have been reported as efficacious biological control agents in protected tomato crops [211,212]. For example, Trichogramma pretiosum (Riley) and Trichogramma achaeae (Nagaraja and Nagarkatti) have been used in T. absoluta management in both native and invaded European regions [213,214]. In Africa, egg parasitoids comprising especially Trichogramma spp. have shown potential for mass releases, e.g., in Tunisia [215]. Indeed, reports suggest that the parasitoid complex for larval T. absoluta comprise approximately 20 hymenopteran species (Table 4) $[207,216,217]$. Similarly, several T. absoluta larval parasitoids, including Eulophids, Braconids and Ichneumonids, have also been reported in the Mediterranean basin [206]. For example, the idiobiont Necremnus artynes parasitising third instars is widely documented [218]. Similarly, in Egypt, the larval parasitoid Stenomesius japonicus has been reported a desirable NS for T. absoluta biocontrol [206], while N. formosa (Westwood) has been reported in the Palearctic area, Asia, Africa and North America [119]. As part of classical biocontrol, the larval parasitoid Dolichogenidea gelechiidivoris Marsh. (Syn.: Apanteles gelechiidivoris Marsh) was introduced from Peru into Africa [72]. Progressive work has shown that D. gelechiidivoris prefers first and second instar larvae and is a highly efficacious parasitoid [72]. Conversely, few T. absoluta pupal parasitoids have been reported [16]. Current research suggests Braconids, Chalcidids, Eulophids and Ichneumonids as potential pupal parasitoids $[15,16,119,219]$ (see Table 4). Given the diversity of African landscapes, and the diversity of both indigenous and exotic natural enemies as potent as NSs in pest control, using these in combination with other compatible NSs may be key to integrated management of T. absoluta in Africa.

Table 4. Natural enemies (parasitoids and predators) reported in literature for Tuta absoluta. The list may not be purely exhaustive but was compiled using the available literature at the time of writing. (Eggs-E; Larvae-L; Pupa-P).

\begin{tabular}{|c|c|c|c|}
\hline Natural Enemy & Species & Host & Reference \\
\hline \multirow[t]{26}{*}{ Parasitoids } & Agathis fuscipennis & $\mathrm{L}$ & [131] \\
\hline & Apanteles dignus & $\mathrm{L}, \mathrm{P}$ & {$[15,16]$} \\
\hline & Apanteles gelechiidivoris & $\mathrm{L}$ & {$[15,16]$} \\
\hline & Baryscapus bruchophagi & $\mathrm{L}$ & [220] \\
\hline & Brachymeria secundaria & $\mathrm{L}$ & [220] \\
\hline & Bracon lucileae & $\mathrm{L}$ & {$[15,16]$} \\
\hline & Bracon lulensis & $\mathrm{L}$ & {$[15,16]$} \\
\hline & Bracon spp. & $\mathrm{P}$ & {$[15,16,119]$} \\
\hline & Bracon tutus & $\mathrm{L}$ & {$[15,16]$} \\
\hline & Campoplex haywardi & $\mathrm{L}$ & {$[15,16]$} \\
\hline & Capidosoma desantis & $\mathrm{E}$ & {$[15,16]$} \\
\hline & Capidosoma koehleri & $\mathrm{E}$ & {$[15,16]$} \\
\hline & Cheolras semele & - & [221] \\
\hline & Closterocerus clarus & $\mathrm{L}$ & [220] \\
\hline & Clostrocerus formosus & $\mathrm{L}$ & {$[15,16]$} \\
\hline & Copidosoma desantisi & $\mathrm{E}$ & {$[15,16]$} \\
\hline & Copidosoma koehleri & $\mathrm{E}$ & {$[15,16]$} \\
\hline & Diadegma spp., D. ledicola and D. pulchripes & $\mathrm{P}$ & {$[15,16,119]$} \\
\hline & Diglyphus crassinervis & $\mathrm{L}$ & [221] \\
\hline & Diglyphus isaea & $\mathrm{L}$ & [221] \\
\hline & Dineulophus phthormiaeae & $\mathrm{L}$ & {$[15,16]$} \\
\hline & Dolichogenidea litae & - & [221] \\
\hline & Elachertus inunctus & $\mathrm{L}$ & [222] \\
\hline & Elasmus phthorimaeae & $\mathrm{L}$ & [221] \\
\hline & Encarsia porteri & $\mathrm{E}$ & [223] \\
\hline & Goniozus nigrifemur & $\mathrm{L}$ & [15] \\
\hline
\end{tabular}


Table 4. Cont.

\begin{tabular}{|c|c|c|c|}
\hline Natural Enemy & Species & Host & Reference \\
\hline & Habrobracon didemie & $\mathrm{L}$ & [220] \\
\hline & Habrobracon hebetor & $\mathrm{L}$ & [220] \\
\hline & Habrobracon nigricans & $\mathrm{L}$ & {$[16,224]$} \\
\hline & Habrobracon osculator & $\mathrm{L}$ & [119] \\
\hline & Halticoptera aenea & $\mathrm{L}$ & [222] \\
\hline & Hemiptarsenus zilahisebessi & $\mathrm{L}$ & [225] \\
\hline & Hockeria unicolor & $\mathrm{L}$ & {$[220,221]$} \\
\hline & Horismenus sp & $\mathrm{P}$ & {$[15,16,119]$} \\
\hline & Hyposoter didymator & - & [226] \\
\hline & Necremnus artynes & $\mathrm{L}$ & {$[218,225]$} \\
\hline & Necremnus metalarus & $\mathrm{L}$ & [206] \\
\hline & Necremnus tidius & $\mathrm{L}$ & [227] \\
\hline & Neochrysocharis formosa & $\mathrm{L}$ & [119] \\
\hline & Neochrysocharis formosa & $\mathrm{L}$ & {$[222,224]$} \\
\hline & Neochrysocharis formosa & $\mathrm{L}$ & {$[15,16]$} \\
\hline & Pnigalio cristatus & $\mathrm{L}$ & {$[220]$} \\
\hline & Pnigalio incompletus & - & [220] \\
\hline & Pnigalio soemius & $\mathrm{L}$ & [221] \\
\hline & Pnigalio sp. soemius complex & $\mathrm{L}$ & [222] \\
\hline & Pseudapanteles dignus & $\mathrm{L}$ & {$[15,16]$} \\
\hline & Pteromalus intermedius & $\mathrm{L}$ & {$[220]$} \\
\hline & Pteromalus semotus & - & [221] \\
\hline & Retisympiesis phthorimaea & $\mathrm{L}$ & {$[15,16]$} \\
\hline & Retisympiesis phthorimaea & $\mathrm{L}$ & {$[15,16]$} \\
\hline & Temelucha anatolica & - & [221] \\
\hline & Trichogramma achaeae & $\mathrm{E}$ & [214] \\
\hline & Trichogramma achaeae & $\mathrm{E}$ & [224] \\
\hline & Trichogramma bactrae & $\mathrm{E}$ & {$[15,16]$} \\
\hline & Trichogramma bourarachae & $\mathrm{E}$ & [228] \\
\hline & Trichogramma dendrolimi & $\mathrm{E}$ & {$[15,16]$} \\
\hline & Trichogramma exiguum & $\mathrm{E}$ & {$[15,16]$} \\
\hline & Trichogramma fasciatum & $\mathrm{E}$ & {$[15,16]$} \\
\hline & Trichogramma lopezandinensis & $\mathrm{E}$ & {$[15,16]$} \\
\hline & Trichogramma minutum & $\mathrm{E}$ & {$[15,16]$} \\
\hline & Trichogramma nerudai & $\mathrm{E}$ & {$[15,16]$} \\
\hline & Trichogramma pintoi & $\mathrm{E}$ & {$[15,16]$} \\
\hline & Trichogramma pretiosum & $\mathrm{E}$ & {$[15,16,213]$} \\
\hline & Trichogramma rojasi & $\mathrm{E}$ & {$[15,16]$} \\
\hline & Trichogramma telengai & E & {$[15,16]$} \\
\hline & Zoophthorus macrops & - & [221] \\
\hline \multirow[t]{17}{*}{ Predators } & Amblyseius cucumeris & $\mathrm{E}, \mathrm{L}$ & [229] \\
\hline & Amblyseius swirskii & $\mathrm{E}, \mathrm{L}$ & [229] \\
\hline & Brachygastra lecheguana & $\mathrm{L}$ & [15] \\
\hline & Calosoma granulatum & $\mathrm{L}, \mathrm{P}$ & [15] \\
\hline & Coleomegilla maculata & E, L & [15] \\
\hline & Cycloneda sanguinea & $\mathrm{E}$ & [15] \\
\hline & Dicyphus errans & $\mathrm{E}, \mathrm{L}$ & [230] \\
\hline & Dicyphus maroccanus & E, L & [230] \\
\hline & Dicyphus. tamaninii & $\mathrm{E}, \mathrm{L}$ & {$[206,229]$} \\
\hline & Doru lineare & $\mathrm{E}$ & [15] \\
\hline & Engytatus varians & $\mathrm{E}$ & [229] \\
\hline & Eriopsis conexa & $\mathrm{E}$ & [15] \\
\hline & Franklinothrips vespiformis & $\mathrm{L}$ & [15] \\
\hline & Labidura riparia & $\mathrm{P}$ & [15] \\
\hline & Lebia concina & $\mathrm{L}, \mathrm{P}$ & {$[15]$} \\
\hline & Macrolophus pygmaeus & $\mathrm{E}, \mathrm{L}$ & [231] \\
\hline & Nabis ibericus & $\mathrm{L}$ & {$[229,232]$} \\
\hline
\end{tabular}


Table 4. Cont.

\begin{tabular}{cccc}
\hline Satural Enemyecies & Host & Reference \\
\hline Nesidiocoris tenuis & $\mathrm{E}$ & {$[231]$} \\
Orius albidipennis & - & {$[230,233]$} \\
Orius insidiosus & $\mathrm{E}, \mathrm{L}$ & {$[15]$} \\
Podisus nigrispinus & $\mathrm{L}$ & {$[15]$} \\
Polistes carnifex & $\mathrm{L}$ & {$[15]$} \\
Polistes melanosoma & $\mathrm{L}$ & {$[15]$} \\
Polistes versicolor & $\mathrm{L}$ & {$[15]$} \\
Polybia ignobilis & $\mathrm{L}$ & {$[15]$} \\
Polybia scutellaris & $\mathrm{L}$ & {$[15]$} \\
Protonectarina sylveirae & $\mathrm{L}$ & {$[15]$} \\
Protopolybia exigua & $\mathrm{L}$ & {$[15]$} \\
Scolothrips sexmaculatus & $\mathrm{L}$ & {$[15]$} \\
Solenopsis geminata & $\mathrm{L}, \mathrm{P}$ & {$[15]$} \\
Solenopsis saevissima & $\mathrm{L}, \mathrm{P}$ & {$[15]$} \\
Synoeca cyanea & $\mathrm{L}$ & {$[15]$} \\
\hline
\end{tabular}

\section{Use of Synthetic Pesticides and Integrated Pest Management}

Regardless of their limitations, chemical pesticides continue to be an important component of integrated pest management (IPM) and can be a crucial pillar in T. absoluta management. Common active ingredients registered for T. absoluta control include pyrethroids [51], organophosphates [3] and diamides [54]. Laboratory bioassays using insecticides with some of these active ingredients showed very high efficacy for T. absoluta control [29,70,234-236]. Despite high laboratory efficacy, field T. absoluta optimal control remains a challenge owing to their cryptic leaf mining behaviour that renders contact insecticides ineffective. In addition, continuous use of these pesticides has also led to resistance development. Insecticides may also have adverse effects on the environment, beneficial arthropods and public health [237]. Thus, minimal insecticidal use is recommended in an IPM approach, which should rather be complemented with more environmentally benign NSs.

IPM encourages the use of eco-friendly strategies, such as NSs in biological control, used in compatible combinations with other efficacious methods, including the use of selective insecticides for pest control [238]. Thus, IPM comprises a cocktail of control practices, which may include cultural, chemical and biological control for the management of an economic pest species (Figure 2) [239]. For T. absoluta management in Africa, and cognisant of all available control options discussed above, we propose the combination of compatible methods in an IPM approach and incorporating the use of sustainable NSs (see Figure 2). This proposition is environmentally friendly, conserves biological diversity, including natural enemy populations, and presents little potentially negative public health implications. With the demerits associated with synthetic insecticides (see, e.g., [53,164]), IPM approaches may provide more lasting sustainable solutions to increased $T$. absoluta pest challenges $[15,60]$ and indeed other pest species.

\section{Potential for Natural Substances in Pest Control: Assets and Liabilities}

\subsection{Legislative and Regulatory Frameworks}

Despite being major pillars to an integrated approach to T. absoluta sustainable management, there are major liabilities and bottlenecks associated with NS development and successful deployment in Africa. Some major liabilities for NSs include the increased number of complex guidelines, regulations and inadequate lobbying by biocontrol champions [240-243]. Furthermore, negative and often conflicting effects on chemical industry profitability and general farmer overreliance on pesticides $[137,242,244]$ are some of the barriers to NSs, biological and low-risk pest management options. Policy guidelines in the production, exportation or importation, shipment, environmental risk assessment and field application of NSs are bureaucratic [240,242-244]. Except for Kenya [245], 
policy and legislation governing NSs in Africa are mostly based on templates for synthetic chemical pesticides with a single active ingredient, and thus does not permit registration of NSs with complex multiple active compounds $[245,246]$. This impedes the ability of resource-poor small and medium enterprises (SMEs) active in the NSs crop protection industry in African countries to register their products $[241,246]$. Governments need to create enabling legal and policy frameworks as pre-requisite for the promotion of the NS industry, particularly promoting existing SMEs [247] relative to multi-national companies. Available evidence suggests that the multi-national companies in the agrochemical industry are "unwilling" participants in creating an enabling legislative and registration environment for the NSs motion [246]. Benjamin and Wesseler [244] suggest that slow adoption of NSs may be caused by prolonged and prohibitive regulations. Therefore, changes in regulatory policies governing NSs in SSA should aim to reduce this bottleneck and make the toxicological evaluation regulations light touch $[240,241,245,246]$. In light of this, African governments remain the main change agents $[242,244,247]$ through policy and regulatory adjustments that promote production, registration and marketing of NSs [246,247].

In some cases, policies on NSs and IPM regulatory guidelines are elaborate on paper but lack implementation [246-248]. This, in part, is supported by the lack of regulation on importation, trade and use as well as residue monitoring of unregistered/highly toxic pesticides $[45,246]$. This may be largely due to a lack of funding [242,247]. Therefore, monetary policies should enact direct funding of implementation of the proven NSs packages. Increased national funding will enhance research and development on NSs and their derivatives [246]. However, research and developments funds are still limited in SSA due to restrictions attached to donor funds [246,249].

Bureaucracy, inefficiency and prolonged government legislative processes are additional impediments to swift changes in NSs policies and legislative regulations [242,246,250]. In addition, difficulty in harmonising regional polices due to fundamental mismatches or disagreements inhibits efficient movement of NSs across borders for purposes of research, propagation, pilot tests or field applications [246]. Sub-Saharan Africa member states may need to adopt a common approach in interpretation of the Acts governing NSs, e.g., harmonised data requirements in toxicological studies or adoption of standard application forms and dossier formats for importation of NSs [240,241,243]. In addition, establishment of a central panel of pan-SSA experts may need to be developed to overlook NSs submissions [243]. If data requirements are harmonised, NSs approved in one country may be accepted in another without the drudgery and costs of repeated efficacy evaluations [241,243].

Encouragingly, related policy structural guidelines are in place for some countries [242]. For example, the organic production of fruits and vegetables, e.g., in Kenya [245,246], has very strict existing legislative measures that may be utilised as pedestals (asset) for building new guidelines for policy adjustments for NSs research and development [241,242,247,249]. Existing policies on conservation of biodiversity and protection of endangered species may be fundamental springboards for policy adjustments for the promotion of NSs. In addition, the Food and Agriculture Organisation (FAO) and Word Health Organisation (WHO) guidelines are freely available for adoption and modification where necessary [251]. The public outcry against pesticide-contaminated food and environment degradation reviewed in $[252,253]$ may also be used as bottom-up pressure to justify policy modifications, promoting the use of NSs. For example, SSA governments can use the substitution principle, by replacing the most toxic pesticides (e.g., WHO hazard classes I and II) with the promising NSs [242,254]. Alternatively, governments can increase tax on the most toxic pesticides and use that revenue to provide subsidies and financial incentives to early adopters or pesticide companies involved in the development of NSs [242,254,255]. As the development and uptake of efficacious NSs increase, this may also positively affect farmer behaviour towards shifting from conventional pesticides to adoption of NSs.

Limited adoption in use of authorised pesticides of NSs is partly attributable to a lack of education and information [45,256-258]. However, evidence exists that some farmers in SSA are traditionally using NSs without anecdotal efficacy and safety validations [246-259]. Based on this, SSA governments 
and other stakeholders alike need to develop and consolidate NS-oriented educational programs to increase ecological literacy and reduce adoption barriers [242,256,258]. It is therefore in the interest of SSA countries to modify policies enabling the development of simplified testing and validation protocols to legitimise existing NSs for improved use and expansion for the greater good.

\subsection{Economic Dynamics}

The economic feasibility of NSs is ingrained in a functional biopesticide industry that, in turn, is rooted in SMEs and small-scale farmers or farmer groups [247,249,260]. This is because large companies are sceptical about the return on investment in NSs due to uncertainties regarding the market size (adoption issues), consistent supply of raw materials, uncertain patent issues and less than absolute efficacy $[242,247,259]$. SMEs in SSA are not well developed due to financial constraints against the backdrop of prohibitive costs of investment on research and development for NSs $[240,247,249]$. Consequently, instead of local production, most SSA agro-companies survive on distributing internationally sourced products [247,259], missing huge local investments opportunities. For example, B. thuringiensis (FlorBac WG ${ }^{\circledR}$ ) and Spinosad (S spinosa, Spintordust ${ }^{\circledR}$ ) distributed by SSA subsidiary agrochemical companies are produced outside the continent [246,247]. This partly contributes to their premium prices, likely aiding their economic non-viability for the majority of resource-constrained farmers in SSA.

Estimation of the full economic value of NSs as a pest management tool is complex and depends on several factors, including the product being protected, the enterprise (e.g., farm), community structure to societal costs and benefits, as reviewed in [244,248]. However, empirical evidence exists in support of financial sustainability for NSs versus conventional insecticides. For example, Amoabeng et al. [249] showed that pesticidal plants were more cost effective than synthetic insecticide in the control of the pests Brevicoryne brassicae (L.) (Hemiptera: Aphididae) and Plutella xylostella (L.) (Lepidoptera: Plutellidae) in cabbage. Similarly, McConnachie et al. [261] showed that the net present value of using a biocontrol agent Stenopelmus rufinasus (Gyllenhal; Coleoptera: Curculionidae) against the red waterfern Azolla filiculoides was US\$1093 per hectare and US\$206 million for the entire South Africa (with a benefit-cost ratio ranging from 2.5:1 to 15:1). While this study documented noble cost savings, Naranjo et al. [248] argues that the economic benefits of NSs are even higher. For example, by factoring avoided costs, e.g., public health protection, environmental damage costs, other maximum incremental social tolerable irreversible costs (MISTICs) and maintenance of essential ecological services [244,262]. Factoring in all these variables thus reflects NSs may be way cheaper both in the short [249] and long term [242,244,263] than conventional pesticides. These arguments reinforce the overall economic viability of NSs as a critical pillar for IPM [242,244,261].

The market for NSs in SSA is underdeveloped, small and highly fragmented due to lack of investment, low ecological consciousness and farmers' skewed behavioural perceptions towards pesticides preference, e.g., [246,249,255], relative to NSs [264,265]. For example, in Ghana, only 14-25\% of the farmer population are using NSs [249]. While studies show that this value may increase with increased education on NSs [242,244,246,249,259], limited funding and stringent regulatory processes still remain significant bottlenecks [244,246,259]. We thus suggest the use of a combination of enabling policy adjustments and direct funding and incentives for biocontrol practitioners to improve NS adoption. Through incentivising SMEs and mobilising farmer or community groups, SSA governments can encourage NS enterprises [249]. This system will build a strong localised production and trading system that can work as an encouraging baseline for private sector investment for scaling up [246,248]. Previous studies suggest scaling up is the main pitfall for research and development initiatives on NSs in SSA [259]. Thus, this can be circumvented by managing the production and trading of NSs using economic product development pathways and commercial imperatives wrapped around government-supported SMEs. 


\subsection{Ecological Perspectives}

The main ecological assets of NSs in SSA include existing freely available rich biodiversity, known trophic systems and established harvesting and rearing/propagation protocols [246,247,250]. Most NSs are highly specific, e.g., EPNs [264], microbial pesticides and parasitoids [265,266]. Thus, they have low impact on beneficial and non-target species [252,266-268] and hence contribute to maintenance of environmental integrity and conservation of biological diversity [242,257]. In addition, production of NSs is ecologically benign and has a low carbon footprint [267]. Plant-based NSs, e.g., natural enemies, have the ability to sustainably self-propagate and disperse in space through inoculative releases [247,250]. This makes NSs a cost-effective management tool. Exhaustive benefits and assets of various NSs for the developing countries have fully been documented [241,248,252,266,269].

The liabilities of some NSs, e.g., predators and parasitoids (Tables 2-4), include dependency on the host pest insect for survival [264,265,270]. This therefore means NSs need the presence of the pest, mediated by density-dependent factors and thus allowing some level of tolerable pest damage. Thus, use of preventive measures for pest management are not possible when using NSs. The action of NSs may also be slow when compared to synthetic insecticides, allowing some degree of pest damage on products. This may be undesirable for pest outbreaks that require rapid efficacy to bring populations below economic thresholds. Furthermore, this may also offset the quality of cosmetic products, e.g., the fruit and vegetable industry, whose Economic Injury Levels (EILs) are low [246]. In addition, some NSs like parasitoids, EPNs and baculoviruses are highly sensitive to the biophysical environment [264-266,271], and thus their efficacy may vary in space. This makes the deployment of NSs challenging in largely rainfed, dry cropping systems in SSA [246] or under rapidly shifting climate environments. Similar environmental limitations for NSs have been made for the biocontrol agents Romanomermis culicivorax [265], Steinernema carpocapsae [272] and other biocontrol approaches [271,273-275].

Other ecological limitations of NSs include a lack of sound and sustainable mass rearing and/propagation technologies that facilitate reliable product supply and reduce the costs of importation while safeguarding ecosystems $[246,247,250]$. Use of botanicals as natural pesticides has been criticised owing to unsustainable harvesting of bioactive plant species $[246,249,250]$. In some cases, effective pesticidal plants that are not native to production areas, e.g., in a push-pull system [185], may become introduced weeds, thus increasing the cost of production. Lack of expertise and experience in the phytochemistry of plant-based NSs for extraction of active ingredients has also been a barrier to success. This expertise is needed for robust evidence-based safety screening to improve research and development processes.

\subsection{Farmer Perceptions and Social Dynamics}

Natural substances are readily available for most small-scale, resource-poor farmers, and thus argued to be the most appropriate technology compatible with SSA [247]. The biggest asset for NSs is its relatively low public health risk. Small-scale farmers are largely poorly advised on the appropriate use and disposal of toxic synthetic pesticides $[45,137,276]$. Compounded by the aggressive promotion of synthetic pesticides that overshadows NSs [244,246,259,277], this makes the use of pesticides a significant public health threat for livelihoods in SSA. There is also limited infrastructure bridging researchers and farmers to facilitate knowledge transfer. As such, most research outputs on NSs remain as pilot projects or scholarly papers that are inaccessible to the small-scale farmers $[244,257,259]$. Nevertheless, behavioural studies show that while SSA farmers are solely used to pesticides, they are willing to adopt NSs if proven efficacious $[45,137,276,278]$. Players in research and development thus need to lobby for uptake of newly developed NSs technologies through engagement with relevant stakeholders.

Fluctuations in supply in NSs, e.g., botanicals, often reduce reliability of this tool for pest management [265]. Furthermore, vulnerability to the biophysical environment often compromises efficacy [248,265], leading to poor product quality and low market values [249]. The application of 
some NSs also requires significant adjustments in current farming methods, labour and skills [277]. For example, the use of parasitoids requires shift from monoculture to habitat management that encourages biodiversity conservation [265,279]. Without change in perception/behaviour, ecological literacy and financial incentives, farmers may not be socially ready for the changes facilitating the use of NSs. Farmers' beliefs, attitude and behaviour are major factors influencing adoption of NSs. Creative persuasion of the non-conformers to NSs is needed to change their choice of pest management approaches [242,244,277]. Indeed, Goldberger et al. [277] showed that out of the three farmer categories, the "environmental stewards" and "networking farmers" are likely to partake in NSs compared to those farmers solely looking to maximise production. Similarly, mobilising farmers into networking groups may increase NS adoption [256,277], e.g., establishing social/networking groups that can implement specific NSs may be a fruitful endeavour for SSA $[255,256]$. These groups also facilitate ease of training and awareness campaigns on ecological literacy, economic feasibility and other assets of NSs.

\section{Conclusions}

The continental invasion of T. absoluta represents a significant biosecurity threat that affects the majority of livelihoods dependant on agricultural sustenance. A number of biological and physiological factors discussed here may, in part, contribute to its current spread in African natural and agro-ecosystems. Insecticide use against T. absoluta has been the common default response to pest pressure. However, pesticide misuse affects the environment, public health, ecosystem services and often leads to pest resistance development. Thus, use of low-risk NSs and biocontrol methods in an integrated approach may be the sustainable solution to the T. absoluta problem in SSA. However, NSs also have their own liabilities as a pest management tool in African systems, argued from a legislative, economic, ecological and social standpoint. Elucidating these factors is critical in facilitating research and development of NSs in Africa and their consequent adoption as a sustainable tool for pest management.

Author Contributions: Conceptualisation, C.N., H.M. and V.L.T.; methodology, C.N., V.L.T., H.M., R.M. and F.C.; validation, C.N., V.L.T., H.M., R.M. and F.C.; resources, C.N. and F.C.; original draft preparation, V.L.T., H.M., R.M. and C.N.; review and editing, C.N., V.L.T., H.M., R.M. and F.C.; supervision, C.N. and F.C.; project administration, C.N. and F.C.; funding acquisition, C.N. All authors have read and agreed to the published version of the manuscript.

Funding: This research received no external funding.

Acknowledgments: The authors would like to acknowledge the Botswana International University of Science and Technology (BIUST) for all financial support availed to V.L.T., H.M. and C.N. and the University of the Free State (UFS) to R.M. and FN. Great appreciation goes to Gerald Chikowore for his input in the construction of Maps used in this paper. We also want to thank several anonymous referees for the valuable inputs in a previous version of this manuscript.

Conflicts of Interest: The authors declare no conflict of interest.

\section{References}

1. Olson, L.J. The economics of terrestrial invasive species: A review of the literature. Agric. Resour. Econ. Rev. 2006, 35, 178-194. [CrossRef]

2. Ragsdale, D.W.; Landis, D.A.; Brodeur, J.; Heimpel, G.E.; Desneux, N. Ecology and management of the soybean aphid in North America. Annu. Rev. Entomol. 2011, 56, 375-399. [CrossRef] [PubMed]

3. Campos, M.R.; Rodrigues, A.R.S.; Silva, W.M.; Silva, T.B.M.; Silva, V.R.F.; Guedes, R.N.C.; Siqueira, H.A.A. Spinosad and the Tomato Borer Tuta absoluta: A Bioinsecticide, an Invasive Pest Threat, and High Insecticide Resistance. PLoS ONE 2014, 9, e103235. [CrossRef] [PubMed]

4. Williamson, M. Biological Invasions; Chapman \& Hall: New York, NY, USA, 1996.

5. Pimentel, D.; McNair, S.; Janecka, J.; Wightman, J.; Simmonds, C.; O’Connell, C.; Wong, E.L.; Russel, L.; Zern, J.; Aquino, T.; et al. Economic and environmental threats of alien plant, animal, and microbe invasions. Agric. Ecosyst. Environ. 2001, 84, 1-20. [CrossRef] 
6. Simberloff, D.; Rejmanek, M. Encyclopedia of Biological Invasions; University of California Press: Berkeley, CA, USA, 2001.

7. van Wilgen, B.W.; Measey, J.; Richardson, D.M.; Wilson, J.R.; Zengeya, T.A. Biological Invasions in South Africa: An Overview. In Biological Invasions in South Africa; Invading Nature-Springer Series in Invasion Ecology; Van Wilgen, B., Measey, J., Richardson, D., Wilson, J., Zengeya, T., Eds.; Springer: Cham, Switzerland, 2020; Volume 14.

8. Tams, W.H.T. New species of African Heterocera. Entomologist 1932, 65, 1241-1249.

9. Dunstan, W.R.; Magazini, I.A. Outbreaks and new records, United Republic of Tanzania. The larger grain borer on stored products. FAO Plant Prot. Bull. 1981, 29, 80-81.

10. Neuenschwander, P. Biological Control of the Cassava Mealybug in Africa: A review. Biol. Control 2001, 21, 214-229. [CrossRef]

11. Lux, S.A.; Copeland, R.S.; White, I.M.; Manrakhan, A.; Billah, M.K. A new invasive fruit fly species from the Bactrocera dorsalis (Hendel) group detected in East Africa. Insect Sci. Appl. 2003, 23, 355-361. [CrossRef]

12. Goergen, G.; Kumar, P.L.; Sankung, S.B.; Togola, A.; Tamo, M. First report of outbreaks of the fall armyworm Spodoptera frugiperda (J E Smith) (Lepidoptera, Noctuidae), a new alien invasive pest in west and central Africa. PLOS ONE 2016, 11, e0165632. [CrossRef]

13. Mansour, R.; Brevault, T.; Chailleux, A.; Cherif, A.; Grissa-Lebdi, K.; Haddi, K.; Mohamed, S.A.; Nofemela, R.S.; Oke, A.; Sylla, S.; et al. Occurrence, biology, natural enemies and management of Tuta absoluta in Africa. Entomol. Gen. 2018, 38, 83-112. [CrossRef]

14. FAO. Comprehensive Africa Agriculture Development Programme (CAADP); NEPAD: Rome, Italy, 2002.

15. Desneux, N.; Wajnberg, E.; Wyckhuys, K.A.G.; Burgio, G.; Arpaia, S.; Narvaez-Vasquez, C.A.; González-Cabrera, J.; Ruescas, D.C.; Tabone, E.; Frandon, J.; et al. Biological invasion of European tomato crops by Tuta absoluta: Ecology, geographic expansion and prospects for biological control. J. Pest. Sci. 2010, 83, 197-215. [CrossRef]

16. Biondi, A.; Guedes, R.N.C.; Wan, F.-H.; Desneux, N. Ecology, Worldwide Spread, and Management of the Invasive South American Tomato Pinworm, Tuta absoluta: Past, Present, and Future. Annu. Rev. Entomol. 2018, 63, 239-258. [CrossRef]

17. Campos, M.R.; Biondi, A.; Adiga, A.; Guedes, R.N.C.; Desneux, N. From the Western Palaearctic region to beyond: Tuta absoluta 10 years after invading Europe. J. Pest Sci. 2017, 90, 787-796. [CrossRef]

18. Han, P.; Zhang, Y.; Lu, Z.; Wang, S.; Ma, D.; Biondi, A.; Desneux, N. Are we ready for the invasion of Tuta absoluta? Unanswered key questions for elaborating an Integrated Pest Management package in Xinjiang, China. Entomol. Gen. 2018, 38, 113-125. [CrossRef]

19. Ghoneim, K. Parasitic insects and mites as potential biocontrol agents for a devastative pest of tomato, Tuta absoluta Meyrick (Lepidoptera: Gelechiidae) in the world: A review. IJRRAS 2014, 19, 3.

20. Marchioro, C.A.; Krechemer, F.S.; Foerster, L.A. Estimating the development rate of the tomato leaf miner, Tuta absoluta (Lepidoptera: Gelechiidae), using linear and non-linear models. Pest Manag. Sci. 2016, 73, 1486-1493. [CrossRef]

21. Urbaneja, A.; Vercher, R.; Navarro-Llopis, V.; Marí, F.; Porcuna, J. The tomato moth, Tuta absoluta. Phytoma Espanã 2007, 194, 16-24. (In Spanish)

22. Guillemaud, T.; Blin, A.; Le Goff, I.; Desneux, N.; Reyes, M.; Tabone, E.; Tsagkarakou, A.; Niño, L.; Lombaert, E. The tomato borer, Tuta absoluta, invading the Mediterranean Basin, originates from a single introduction from Central Chile. Sci. Rep. 2015, 5, 8371. [CrossRef]

23. Desneux, N.; Luna, M.G.; Guillemaud, T.; Urbaneja, A. The invasive South American tomato pinworm, Tuta absoluta, continues to spread in Afro-Eurasia and beyond: The new threat to tomato world production. J. Pest Sci. 2011, 84, 403-408. [CrossRef]

24. Guimapi, R.Y.A.; Mohamed, S.A.; Okeyo, G.O.; Ndjomatchoua, F.T.; Ekesi, S.; Tonnang, H.E.Z. Modeling the risk of invasion and spread of Tuta absoluta in Africa. Ecol. Complex. 2016, 28, 77-93. [CrossRef]

25. Abbes, K.; Harbi, A.; Chermiti, B. The tomato leafminer Tuta absoluta, (Meyrick) in Tunisia: Current status and management strategies. Bull. OEPP 2012, 42, 226-233. [CrossRef]

26. Shashank, P.R.; Suroshe, S.; Singh, S.; Chandrashekar, K.; Nebapure, N.M.; Meshram, N. Report of invasive tomato leaf miner, Tuta absoluta (Lepidoptera: Gelechiidae) from Northern India. Indian J. Agric. Sci. 2016, 86, $1635-1636$. 
27. Bajracharya, A.; Mainali, R.P.; Bhat, B.; Bista, S.; Shashank, P.R.; Meshram, N. The first record of South American tomato leaf miner, Tuta absoluta (Meyrick 1917) (Lepidoptera: Gelechiidae) in Nepal. J. Entomol. Zool. Stud. 2016, 4, 1359-1363.

28. Sankarganesh, E.; Firake, D.M.; Sharma, B.; Verma, V.K.; Behere, G.T. Invasion of the South American Tomato Pinworm, Tuta absoluta, in North-eastern India: A new challenge and biosecurity concerns. Entomol. Gen. 2017, 36, 335-345. [CrossRef]

29. CABI. Tomato Leafminer (Tuta absoluta): IMPACTS and Coping Strategies for Africa; CABI: Wallingford, UK, 2019.

30. Mohamed, E.S.I.; Mohamed, M.E.; Gamiel, S.A. First record of the tomato leafminer, Tuta absoluta (Meyrick) (Lepidoptera: Gelechiidae) in Sudan. EPPO Bull. 2012, 42, 325-327. [CrossRef]

31. El-Arnaouty, S.A.; Pizzol, J.; Galal, H.H.; Kortam, M.N.; Afifi, A.I.; Beyssat, V.; Desneux, N.; Biondi, A.; Heikal, I.H. Assessment of two Trichogramma species for the control of Tuta absoluta in North African tomato greenhouses. Afr. Entomol. 2014, 22, 801-809. [CrossRef]

32. Pfeiffer, D.G.; Muniappan, R.; Sall, D.; Diatta, P.; Diongue, A.; Dieng, E.O. First Record of Tuta absoluta (Lepidoptera: Gelechiidae) in Senegal. Fla. Entomol. 2013, 96, 661-662. [CrossRef]

33. Tumuhaise, V.; Khamis, F.M.; Agona, A.; Sseruwu, G.; Mohamed, S.A. First record of Tuta absoluta (Lepidoptera: Gelechiidae) in Uganda. Int. J. Trop. Insect Sci. 2016, 36, 135-139. [CrossRef]

34. Chidege, M.; Al-zaidi, S.; Hassan, N.; Julie, A.; Kaaya, E.; Mrogoro, S. First record of tomato leaf miner Tuta absoluta (Meyrick) (Lepidoptera: Gelechiidae) in Tanzania. Agric. Food Secur. 2016, 5, 17. [CrossRef]

35. IPPC. First detection of Tuta absoluta in South Africa. Report ZAF-31/1. International Plant Protection Convention. 2016. Available online: https://www.ippc.int/en/countries/south-africapestreports/2016/09/firstdetection-oftuta-absoluta-in-south-africa (accessed on 30 March 2020).

36. Mutamiswa, R.; Machekano, H.; Nyamukondiwa, C. First report of tomato leaf miner, Tuta absoluta (Meyrick) (Lepidoptera: Gelechiidae), in Botswana. Agric. Food Secur. 2017, 6, 49. [CrossRef]

37. Visser, D.; Uys, V.M.; Nieuwenhuis, R.J.; Pieterse, W. First records of the tomato leaf miner Tuta absoluta (Meyrick. (Lepidoptera: Gelechiidae) in South Africa. Biol. Invasions 2017, 6, 301-305.

38. Zhang, G.; Ma, D.; Wang, Y.; Gao, Y.; Liu, W.; Zhang, R.; FU, W.; Xian, X.; Wang, J.; Kuang, M.; et al. First report of the South American tomato leafminer, Tuta absoluta (Meyrick), in China. J. Integr. Agric. 2020, 19, 1912-1917. [CrossRef]

39. Tarusikirwa, V.L.; Mutamiswa, R.; English, S.; Chidawanyika, F.; Nyamukondiwa, C. Thermal plasticity in the invasive south American tomato pinworm Tuta absoluta (Meyrick) (Lepidoptera: Gelechiidae). J. Therm. Biol. 2020. [CrossRef] [PubMed]

40. Mohamed, E.S.I.; Mahmoud, M.E.E.; Elhaj, M.A.M.; Mohamed, S.A.; Ekesi, S. Host plants record for tomato leaf miner Tuta absoluta (Meyrick) in Sudan. EPPO Bull. 2015, 45, 108-111. [CrossRef]

41. Özgökçe, M.S.; Bayindir, A.; Karaca, I. Temperature-dependent development of the tomato leaf miner, Tuta absoluta (Meyrick) (Lepidoptera: Gelechiidae) on tomato plant Lycopersicon esculentum Mill. (Solanaceae). Turkish J. Entomol. 2016, 40, 51-59. [CrossRef]

42. Machekano, H.; Mutamiswa, R.; Nyamukondiwa, C. Evidence of rapid spread and establishment of Tuta absoluta (Meyrick) (Lepidoptera: Gelechiidae) in semi-arid Botswana. Agric. Food Secur. 2018, 7, 48. [CrossRef]

43. Tonnang, H.E.Z.; Mohamed, S.A.; Khamis, F.; Ekesi, S. Identification and risk assessment for worldwide invasion and spread of Tuta absoluta with a focus on Sub-Saharan Africa: Implications for phytosanitary measures and management. PLoS ONE 2015, 10, e0138319. [CrossRef]

44. Biondi, A.; Desneux, N. Special issue on Tuta absoluta: Recent advances in management methods against the background of an ongoing worldwide invasion. J. Pest Sci. 2019, 92, 1313-1315. [CrossRef]

45. Machekano, H.; Mvumi, B.M.; Nyamukondiwa, C. Plutella xylostella (L.): Pest status, control practices, perceptions and knowledge on existing and alternative management options in arid small-scale farming environments. Int. J. Pest Manag. 2020, 66, 48-64. [CrossRef]

46. Silva, G.A.; Picanco, M.C.; Bacci, L.; Crespo, A.L.B.; Rosado, J.F.; Guedes, R.N.C. Control failure likelihood and spatial dependence of insecticide resistance in the tomato pinworm, Tuta absoluta. Pest Manag. Sci. 2011, 67, 913-920. [CrossRef]

47. Cocco, A.; Deliperi, S.; Delrio, G. Control of Tuta absoluta (Meyrick) (Lepidoptera: Gelechiidae) in greenhouse tomato crops using the mating disruption technique. J. Appl. Entomol. 2013, 137, 16-28. [CrossRef] 
48. Bawin, T.; Dujeu, D.; De Backer, L.; Francis, F.; Verheggen, F.J. Ability of Tuta absoluta (Lepidoptera: Gelechiidae) to develop on alternative host plant species. Can. Entomol. 2016, 148, 434-442. [CrossRef]

49. Margni, M.; Rossier, D.; Crettaz, P.; Jolliet, O. Life cycle impact assessment of pesticides on human health and ecosystems. Agric. Ecosyst. Environ. 2002, 93, 379-392. [CrossRef]

50. Abdollahi, M.; Ranjbar, A.; Shadnia, S.; Nikfar, S.; Rezaie, A. Pesticides and oxidative stress: A review. Med. Sci. Monit. 2004, 10, 141-147.

51. Guedes, R.N.C.; Picanço, M.C. The tomato borer Tuta absoluta in South America: Pest status, management and insecticide resistance. Bull. OEPP/EPPO 2012, 42, 211-216. [CrossRef]

52. Roditakis, E.; Vasakis, E.; García-Vidal, L.; del Rosario Martínez-Aguirre, M.; Rison, J.L.; Haxaire-Lutun, M.O.; Nauen, R.; Tsagkarakou, A.; Bielza, P. A four-year survey on insecticide resistance and likelihood of chemical control failure for tomato leafminer T. absoluta in the European/Asian region. J. Pest Sci. 2018, 91, 421-435.

53. Lietti, M.M.M.; Botto, E.; Alzogaray, R.A. Insecticide resistance in Argentine populations of Tuta absoluta (Meyrick) (Lepidoptera: Gelechiidae). Neotrop. Entomol. 2005, 34, 113-119. [CrossRef]

54. Roditakis, E.; Vasakis, E.; Grispou, M.; Stavrakaki, M.; Nauen, R.; Gravouil, M.; Bassi, A. First report of T. absoluta resistance to diamide insecticides. J. Pest Sci. 2015, 88, 9-16. [CrossRef]

55. Biondi, A.; Mommaerts, V.; Smagghe, G.; Viñuela, E.; Zappalà, L.; Desneux, N. The non-target impact of spinosyns on beneficial arthropods. Pest Manag. Sci. 2012, 68, 1523-1536. [CrossRef]

56. van der Velden, N.; Suay, R.; Urbaneja, A.; Giorgini, M.; Ruocco, M.; Poncet, C.; Lefèvre, A. Recent Developments and Market Opportunities for IPM in Greenhouse Tomatoes in Southern Europe; Consequences for Advanced IPM Toolboxes and Greenhouse Engineering; LEI Memorandum 12-077; LEI Wageningen UR: The Hague, The Netherlands, 2012; p. 41.

57. Mossa, A.T.H. Green pesticides: Essential oils as biopesticides in insect-pest management. Environ. Sci. Technol. 2016, 9, 354-378. [CrossRef]

58. Soares, M.A.; Campos, M.R.; Passos, L.C.; Carvalho, G.A.; Haro, M.M.; Lavoir, A.V.; Biondi, A.; Zappalà, L.; Desneux, N. Botanical insecticide and natural enemies: A potential combination for pest management against Tuta absoluta. J. Pest. Sci. 2019, 92, 1433-1443. [CrossRef]

59. Witzgall, P.; Kirsch, P.; Cork, A. Sex Pheromones and Their Impact on Pest Management. J. Chem. Ecol. 2010, 36, 80-100. [CrossRef] [PubMed]

60. Tsoulnara, D.; Port, G. Efficacy of a Beauveria bassiana strain, Bacillus thuringiensis and their combination against the tomato leafminer Tuta absoluta. Entomol. Hell. 2016, 25, 23-30. [CrossRef]

61. Hikal, W.M.; Baeshen, R.S.; Said-Al Ahl, H.A.S. Botanical insecticide as simple extractives for pest control. Cogent Biol. 2017, 3, 1404274. [CrossRef]

62. Kamali, S.; Karimi, J.; Koppenhöfer, A.M. New Insight into the Management of the Tomato Leaf Miner, Tuta absoluta (Lepidoptera: Gelechiidae) with Entomopathogenic Nematodes. J. Econ. Entomol. 2018, 111, 112-119. [CrossRef]

63. Lengai, G.M.W.; Muthomi, J.W.; Mbega, E.R. Phytochemical activity and role of botanical pesticides in pest management for sustainable agricultural crop production. Sci. Afr. 2020, 7, e00239. [CrossRef]

64. Guedes, R.N.C.; Roditakis, E.; Campos, M.R.; Haddi, K.; Bielza, P.; Siqueira, H.A.A.; Tsagkarakou, A.; Vontas, J.; Nauen, R. Insecticide resistance in the tomato pinworm Tuta absoluta: Patterns, spread, mechanisms, management and outlook. J. Pest. Sci. 2019, 92, 1329-1342. [CrossRef]

65. Deng, A.; Ogendo, J.O.; Owuor, G.; Bett, P.K.; Omolo, E.O.; Mugisha-Kamatenesi, M.; Mihale, J.M. Factors determining the use of botanical insect pest control methods by small-holder farmers in the Lake Victoria basin, Kenya. J. Environ. Sci. Technol. 2009, 3, 108-115.

66. Stevenson, P.; Isman, M.B.; Belmain, S. Pesticidal plants in Africa: A global vision of new Biol. Cntrol products from local uses. Ind. Crops Prod. 2017. [CrossRef]

67. FAO. The State of Food Insecurity in the World: Economic Growth Is Necessary But Not Sufficient to Accelerate Reduction of Hunger and Malnutrition; FAO: Rome, Italy, 2012.

68. Ndor, D.C. Incidence of Tomato leaf miner (Tuta absoluta: Meyrick) damage on Tomato fields in Pankshin and Kanke Local Government Areas of Plateau State. Agric. Sci. Res. J. 2018, 8, 15-19.

69. Weinberger, K.; Lumpkin, T.A. Diversification into horticulture and poverty reduction: A research agenda. World Dev. 2007, 35, 1464-1480. [CrossRef]

70. Bala, I.; Mukhtar, M.; Saka, H.; Abdullahi, N.; Ibrahim, S. Determination of insecticide susceptibility of field populations of tomato leaf miner (Tuta absoluta) in Northern Nigeria. Agriculture 2019, 9, 7. [CrossRef] 
71. FAOSTAT (Food Agric. Org. U. N.). FAOSTAT Statistics Database; FAOSTAT: Rome, Italy, 17 May 2017; Available online: http://www.fao.org/faostat (accessed on 24 April 2017).

72. Aigbedion-Atalor, P.O.; Mohameda, A.S.; Hill, M.P.; Zaluckic, M.P.; Azrag, A.G.A.; Srinivasan, R.; Ekesi, S. Host stage preference and performance of Dolichogenidea gelechiidivoris (Hymenoptera: Braconidae), a candidate for classical Biol. Cntrol of Tuta absoluta in Africa. Biol. Control 2020, 144, 104215. [CrossRef]

73. Shahbaz, M.; Nouri-Ganbalani, G.; Naseri, B. Comparative damage and digestive enzyme activity of Tuta absoluta (Meyrick) (Lepidoptera: Gelechiidae) on 12 tomato cultivars. Entomol. Res. 2017, 49, 401-408. [CrossRef]

74. Kaoud, H.A. Alternative methods for the control of Tuta absoluta. Glob. J. Multidiscip. Appl. Sci. 2014, 2, $41-46$.

75. Sanda, N.B.; Sunusi, M.; Hamisu, H.S.; Wudil, B.S.; Sule, H.; Abdullahi, A.M. Biological invasion of tomato leafminer, Tuta absoluta (Meyrick) in Nigeria: Problems and management strategies optimization: A Review. Asian J. Agric. Horti. Res. 2018, 1, 1-14.

76. Chidege, M.; Abel, J.; Afonso, Z.; Tonini, M.; Fernandez, B. Tomato leaf miner, Tuta absoluta (Meyrick) (Lepidoptera: Gelechiidae) detected in Namibe Province Angola. J. Appl. Life Sci. 2017, 12, 1-5. [CrossRef]

77. European and Mediterranean Plant Protection Organization. EPPO A1 and A2 List of Pests Recommended for Regulation as Quarantine Pests. 2014. Available online: http://www.eppo.int/QUARANTINE/listA2.htm (accessed on 1 December 2014).

78. Xian, X. The Potential Invasion Risk of the Tomato Leafminer Tuta absoluta in China; Institute of Plant Protection, Chinese Academy of Agricultural Science: Beijing, China, 2017.

79. Karadjova, O.; Ilieva, Z.; Krumov, V.; Petrova, E.; Ventsislavov, V. Tuta absoluta (Meyrick) (Lepidoptera: Gelechiidae): Potential for entry, establishment and spread in Bulgaria. Bulg. J. Agric. Sci. 2013, 19, 563-571.

80. Potting, R.P.J.; van der Gaag, D.J.; Loomans, A.; van der Straten, M.; Anderson, H.; MacLeod, A.; Castrillón, J.M.G.; Cambra, G.V. Tuta absoluta, Tomato Leaf Miner Moth or South American Tomato Moth—Pest Risk Analysis for Tuta absoluta; Ministry of Agriculture, Nature and Food Quality, Plant Protection Service of the Netherlands: Utrecht, The Netherlands, 2013.

81. Illakwahhi, D.T.; Srivastava, B.B.L. Control and management of tomato leafminer-Tuta absoluta (Meyrick) (Lepidoptera, Gelechiidae). A Review. IOSR J. Appl. Chem. 2017, 10, 14-22. [CrossRef]

82. Retta, A.N.; Berhe, D.H. Tomato leaf miner-Tuta absoluta (Meyrick), a devastating pest of tomatoes in the highlands of Northern Ethiopia: A call for attention and action. Res. J. Agric. Environ. Manag. 2015, 4, 264-269.

83. Davies, K.F.; Chesson, P.; Harrison, S.; Inouye, B.D.; Melbourne, B.A.; Rice, K.J. Spatial heterogeneity explains the scale dependence of the native-exotic diversity relationship. Ecology 2005, 86, 1602-1610. [CrossRef]

84. Richardson, D.; Pysek, P. Plant invasions: Merging the concepts of species invasiveness and community invasibility. Prog. Phys. Geogr. 2006, 30, 409-431. [CrossRef]

85. Crespo-Pérez, V.; Rebaudo, F.; Silvain, J.-F.; Dangles, O. Modeling invasive species spread in complex landscapes: The case of potato moth in Ecuador. Landsc. Ecol. 2011, 26, 1447-1461. [CrossRef]

86. Osawa, T.; Mitsuhashi, H.; Niwa, H. Many alien invasive plants disperse against the direction of stream flow in riparian areas. Ecol. Complex. 2013, 15, 26-32. [CrossRef]

87. Ward, N.L.; Masters, G.J. Linking climate change and species invasion: An illustration using insect herbivores. Glob. Chang. Biol. 2007, 13, 1605-1615. [CrossRef]

88. Bacon, S.J.; Aebi, A.; Calanca, P.; Bacher, S. Quarantine arthropod invasions in Europe: The role of climate, hosts and propagule pressure. Divers. Distrib. 2014, 20, 84-94. [CrossRef]

89. Walther, G.R.; Roques, A.; Hulme, P.E.; Sykes, M.T.; Pyšek, P.; Kühn, I.; Zobel, M.; Bacher, S.; Botta-Dukat, Z.; Bugmann, H.; et al. Alien species in a warmer world: Risks and opportunities. Trends Ecol. Evol. 2009, 24, 686-693. [CrossRef]

90. Santana, P.A.; Kumar, L.; Da Silva, R.S.; Picanço, M.C. Global geographic distribution of Tuta absoluta as affected by climate change. J. Pest. Sci. 2019, 92, 1373-1385. [CrossRef]

91. Barrientos, Z.R.; Apablaza, H.J.; Norero, S.A.; Estay, P.P. Threshold temperature and thermal constant for development of the South American tomato moth, Tuta absoluta (Lepidoptera, Gelechiidae). Cienc. Investig. Agrar. 1998, 25, 133-137. [CrossRef] 
92. Martins, J.C.; Picanço, M.C.; Bacci, L.; Guedes, R.N.C.; Santana, P.A., Jr.; Ferreira, D.O.; Chediak, M. Life table determination of thermal requirements of the tomato borer Tuta absoluta. J. Pest Sci. 2016, 89, 897-908. [CrossRef]

93. Krechemer, F.S.; Foerster, L.A. Tuta absoluta (Lepidoptera: Gelechiidae): Thermal requirements and effect of temperature on development, survival, reproduction and longevity. Eur. J. Entomol. 2015, 112, 658-663. [CrossRef]

94. Notz, A.P. Distribution of eggs and larvae of Scrobipalpula absoluta in potato plants. Revista de la Facultad de Agronomia (Maracay) 1992, 18, 425-432.

95. Cuthbertson, A.G.; Mathers, J.J.; Blackburn, L.F.; Korycinska, A.; Luo, W.; Jacobson, R.J.; Northing, P. Population Development of Tuta absoluta (Meyrick) (Lepidoptera: Gelechiidae) under Simulated UK Glasshouse Conditions. Insects 2013, 4, 185-197. [CrossRef] [PubMed]

96. Sylla, S.; Seydi, O.; Diarra, K.; Brevault, T. Seasonal decline of the tomato leafminer, Tuta absoluta, in the shifting landscape of a vegetable-growing area. Entomol. Exp. Appl. 2018, 66, 638-647. [CrossRef]

97. Lee, C.E. Evolutionary genetics of invasive species. Trends Ecol. Evol. 2002, 17, 386-391. [CrossRef]

98. Nyamukondiwa, C.; Kleynhans, E.; Terblanche, J.S. Phenotypic plasticity of thermal tolerance contributes to the invasion potential of Mediterranean fruit flies (Ceratitis capitata). Ecol. Entomol. 2010, 35, 565-575. [CrossRef]

99. Weldon, C.W.; Boardman, L.; Marlin, D.; Terblanche, J.S. Physiological mechanisms of dehydration tolerance contribute to the invasion potential of Ceratitis capitata (Wiedemann) (Diptera: Tephritidae) relative to its less widely distributed congeners. Front. Zool. 2016, 13, 15. [CrossRef]

100. Crowl, T.A.; Crist, T.O.; Parmenter, R.R.; Belovsky, G.; Lugo, A.E. The spread of invasive species and infectious disease as drivers of ecosystem change. Front. Ecol. Environ. 2008, 6, 238-246. [CrossRef]

101. Olyarnik, S.V.; Bracken, M.E.; Byrnes, J.E.; Hughes, A.R.; Hultgren, K.M.; Stachowicz, J.J. Ecological Factors Affecting Community Invasibility. In Biological Invasions in Marine Ecosystems; Rilov, G., Crooks, J., Eds.; Springer: Berlin/Heidelberg, Germany, 2009; pp. 215-238.

102. Chown, S.L.; Terblanche, J.S. Physiological Diversity in Insects: Ecological and evolutionary contexts. Adv. Insect Physiol. 2007, 33, 50-152.

103. Mutamiswa, R.; Chidawanyika, F.; Nyamukondiwa, C. Thermal plasticity potentially mediates the interaction between host Chilo partellus Swinhoe (Lepidoptera: Crambidae) and endoparasitoid Cotesia flavipes Cameron (Hymenoptera: Braconidae) under rapidly changing environments. Pest Manag. Sci. 2018, 74, 1335-1345. [CrossRef]

104. Tarusikirwa, V.L.; Mutamiswa, R.; Chidawanyika, F.; Nyamukondiwa, C. Cold hardiness of the South American tomato pinworm Tuta absoluta (Lepidoptera: Gelechiidae): Both larvae and adults are chill-susceptible. Pest Manag. Sci. 2020. [CrossRef] [PubMed]

105. Pereya, P.C.; Sanchez, N.E. Effect of two Solanaceous plants on development and population parameters of the tomato leaf miner (Tuta absoluta Meyrick) (Lepidoptera: Gelechiidae). Neotrop. Entomol. 2006, 35, 671-676. [CrossRef] [PubMed]

106. Tropea Garzia, G.; Siscaro, G.; Biondi, A.; Zappalà, L. Tuta absoluta, a South American pest of tomato now in the EPPO region: Biology, distribution and damage. Bull. OEPP/EPPO 2012, 42, 205-210. [CrossRef]

107. Van Damme, V.; Berkvens, N.; Moerkens, R.; Berckmoes, E.; Wittemans, L.; De Vis, R.; Casteels, H.; Tirry, L.; De Clercq, P. Overwintering potential of the invasive leafminer Tuta absoluta (Meyrick) (Lepidoptera: Gelechiidae) as a pest in greenhouse tomato production in Western Europe. J. Pest. Sci. 2015, 88, 533-541. [CrossRef]

108. Uchôa-Fernandes, M.A.; Della Lucia, T.M.C.; Vilela, E.F. Mating, oviposition and pupation of Scrobipalpula absoluta (Meyrick) (Lepidoptera: Gelechiidae). An. Soc. Entomol. Bras. 1995, 24, 159-164.

109. Engelbrecht, F.; Adegoke, J.; Bopape, M.J.; Naidoo, M.; Garland, R.; Thatcher, M.; Gatebe, C. Projections of rapidly rising surface temperatures over Africa under low mitigation. Environ. Res. Lett. 2015, 10, 085004. [CrossRef]

110. Middleton, B.A. Invasive Plant Species. In Encyclopedia of Ecology, 2nd ed.; Fath, B., Ed.; Elsevier: Amsterdam, The Netherlands, 2019; pp. 431-440.

111. Lockwood, J.L.; Cassey, P.; Blackburn, T. The role of propagule pressure in explaining species invasions. Trends Ecol. Evol. 2005, 20, 223-228. [CrossRef] 
112. Sax, D.F.; Stachowicz, J.J.; Brown, J.H.; Bruno, J.F.; Dawson, M.N.; Gaines, S.D.; Grosberg, R.K.; Hastings, A.; Holt, R.D.; Mayfield, M.M.; et al. Ecological and evolutionary insights from species invasions. Trends Ecol. Evol. 2007, 22, 465-471. [CrossRef]

113. Keane, R.M.; Crawley, M.J. Exotic plant invasions and the enemy release hypothesis. Trends Ecol. Evol. 2002, 17, 164-170. [CrossRef]

114. Selvaraj, S.; Ganeshamoorthi, P.; Pandiaraj, T. Potential impacts of recent climate change on biological control agents in agro-ecosystem: A review. Int. J. Biodivers. Conserv. 2013, 5, 845-852.

115. Wolfe, L.M. Why alien invaders succeed: Support for the escape-from-enemy hypothesis. Am. Nat. 2002, 160, 705-711. [CrossRef] [PubMed]

116. Torchin, M.E.; Lafferty, K.D.; Dobson, A.P.; McKenzie, V.J.; Kuris, A.M. Introduced species and their missing parasites. Nature 2003, 421, 628-630. [CrossRef] [PubMed]

117. Colautti, R.I.; Ricciardi, A.; Grigorovich, I.A.; MacIsaac, H.J. Is invasion success explained by the enemy release hypothesis? Ecol. Lett. 2004, 7,721-733. [CrossRef]

118. Meijer, K.; Schilthuizen, M.; Beukeboom, L.; Smit, C. A review and meta-analysis of the enemy release hypothesis in plant-herbivorous insect systems. Peer] 2016, 4, e2778. [CrossRef] [PubMed]

119. Zappalá, L.; Biondi, A.; Alma, A.; Al-Jboory, I.J.; Arnò, J.; Bayram, A.; Chailleux, A.; El-Arnaouty, A.; Gerling, D.; Guenaoui, Y.; et al. Natural enemies of the South American moth, Tuta absoluta, in Europe, North Africa and Middle East, and their potential use in pest control strategies. J. Pest Sci. 2013, 86, 635-647. [CrossRef]

120. Salas Gervassio, N.G.; Aquino, D.; Vallina, C.; Biondi, A.; Luna, M.G. A re-examination of Tuta absoluta parasitoids in South America for optimized biological control. J. Pest. Sci. 2019, 92, 1343-1357. [CrossRef]

121. Idriss, G.E.A.; Mohamed, S.A.; Khamis, F.; Du Plessis, H.; Ekesi, S. Biology and performance of two indigenous larval parasitoids on Tuta absoluta (Lepidoptera: Gelechiidae) in Sudan. Biocontrol Sci. Technol. 2018, 28, 614-628. [CrossRef]

122. Oke, O.A.; Kolawole, R.O.; Ogunremi, O.A.; Akinsola, O.A.; Awe, S.A. Detection of Apanteles spp (Hymenoptera: Braconidae) larval parasitoid of tomato leafminer Tuta absoluta (Lepidoptera: Gelechiidae) on greenhouse tomato in Abeokuta, Ogun state, Nigeria. In Proceedings of the 25th International Congress of Entomology-Program Book, Orlando, FL, USA, 25-30 September 2016; p. 318.

123. Zlof, V.; Suffert, M. Report of the EPPO/FAO/IOBC/NEPPO Joint International Symposium on management of Tuta absoluta (tomato borer). Bull. OEPP/EPPO 2012, 42, 203-204. [CrossRef]

124. Husariu, V.; Bădulescu, L.; Ciceoi, R. Tuta absoluta (Lepidoptera: Gelechiidae)—What impact for biodiversity? In Proceedings of the International Symposium ISB-Inma-Teh Agricultural and Mechanical Engineering, Bucharest, Romania, 26-28 October 2017.

125. Abbes, K.; Harbi, A.; Elimem, M.; Hafsi, A.; Chermiti, B. Bioassay of three solanaceous weeds as alternative hosts for the invasive tomato leafminer Tuta absoluta (Lepidoptera: Gelechiidae) and insights on their carryover potential. Afr. Entomol. 2016, 24, 334-342. [CrossRef]

126. Drouai, H.; Mimeche, F.; Zedam, A.; Mimeche, H.; Mohammed Belhamra and Mohamed Biche. New floristic records of Tuta absoluta Meyrick 1917, in Zibans's Oasis (Biskra Algeria). J. Entomol. Zool. Stud. 2016, 4, 130-132.

127. Younes, A.A.; Zohdy, Z.M.N.; Abul, F.H.; Fathy, R. Preference and Performance of the Tomato Leafminer, Tuta absoluta (Lepidoptera-Gelechiidae) Towards Three Solanaceous Host Plant Species. CPQ Microbiol. 2018, 1, 1-16.

128. Gebremariam, G. Tuta absoluta: A global looming challenge in tomato production, Review paper. J. Biol. Agric. Healthc. 2015, 5, 57-62.

129. Galarza, J. Evaluacion en laboratorio de Algunas Plantas Solanaceas. Posibles Hospederas de la Polilla del Tomate Scrobipapula absoluta (Meyr.) (Lepidoptera: Gelechiidae). IDIA 1984, 421-424, 30-32.

130. Fernandez, S.; Montagne, A. Preferencia de oviposicion de las hembras y duracion, crecimiento y sobrevivencia de las larvas de Scrobipalpula absoluta (Meyrick). Bol. Entomol. Venez NS 1990, 5, 89-99.

131. Loni, A.; Rossi, E.; Van Achterberg, C. First report of Agathis fuscipennis in Europe as parasitoid of the tomato leafminer Tuta absoluta. Bull. Insectology 2011, 64, 115-117.

132. EPPO. EPPO datasheets on quarantine pests: Tuta absoluta. EPPO Bull. 2005, 35, 434-435. [CrossRef] 
133. Garzia, G.T. Physalis peruviana L. (Solanaceae), a host plant of Tuta absoluta in Italy. In Proceedings of the Integrated Control and Protected Crops, Mediterranean Climate. IOBC/WPRS Working Group Meeting, Crete, Greece, 7-10 September 2009.

134. Portakaldali, M.; Öztemiz, S.; Kütük, H. A new host plant for Tuta absoluta (Meyrick) (Lepidoptera: Gelechiidae) in Turkey. J. Entomol. Res. Soc. 2013, 15, 21-24.

135. Nitin, K.S.; Chakravarthy, A.K.; Sridhar, V. First report of South American Tomato moth, Tuta absoluta (Meyrick) on French bean from India. J. Appl. Hort. 2017, 19, 253-254. [CrossRef]

136. Borisade, O.A.; Kolawole, A.O.; Adebo, G.M.; Uwaidem, Y.I. The tomato leafminer (Tuta absoluta) (Lepidoptera: Gelechiidae) attack in Nigeria: Effect of climate change on over-sighted pest or agro-bioterrorism? J. Agric. Ext. Rural Dev. 2017, 9, 163-171. [CrossRef]

137. Williamson, S.; Ball, A.; Pretty, J. Trends in pesticide use and drivers for safer pest management in four African countries. Crop Prot. 2008, 27, 1327-1334. [CrossRef]

138. Zekeya, N.; Chacha, M.; Ndakidemi, P.A.; Materu, C.; Chidege, M.; Mbega, E.R. Tomato Leafminer (Tuta absoluta Meyrick 1917): A Threat to Tomato Production in Africa. J. Agric. Ecol. Res. Int. 2017, 10, 1-10.

139. Siqueira, H.A.A.; Guedes, R.N.C.; Picanço, M.C. Insecticide resistance in populations of Tuta absoluta (Lepidoptera: Gelechiidae). Agric. Forest Entomol. 2000, 2, 147-153. [CrossRef]

140. Brévault, T.; Achaleke, J.; Sougnabé, S.; Vaissayre, M. Tracking pyrethroid resistance in the polyphagous bollworm, Helicoverpa armigera (Lepidoptera: Noctuidae), in the shifting landscape of a cotton-growing area. Bull. Entomol. Res. 2008, 98, 565-573. [CrossRef]

141. Haddi, K.; Berger, M.; Bielza, P.; Cifuentes, D.; Field, L.M.; Gorman, K.; Rapisarda, C.; Williamson, M.S.; Affiliations, C.B. Identification of mutations associated with pyrethroid resistance in the voltage-gated sodium channel of the tomato leaf miner (Tuta absoluta). Insect Biochem. Mol. 2012, 42, 506-513. [CrossRef] [PubMed]

142. Roditakis, E.; Skarmoutsou, C.; Staurakaki, M. Toxicity of insecticides to populations of tomato borer Tuta absoluta (Meyrick) from Greece. Pest Manag. Sci. 2013, 69, 834-840. [CrossRef] [PubMed]

143. El-Wakeil, N.E. Botanical Pesticides and Their Mode of Action. Gesunde Pflanz. 2013, 65, 125-149. [CrossRef]

144. Bowers, M.D.; Puttick, G.M. Iridoid glycosides and insect feeding preferences: Gypsy moths (Lymantria dispar, Lymantriidae) and buckeyes (Junonia coenia, Nymphalidae). Ecol. Entomol. 1989, 14, 247-256. [CrossRef]

145. Gould, K.S.; Lister, C. Flavonoid Functions in Plants. In Flavonoids: Chemistry, Biochemistry, and Applications; CRC Press LLC: Boca Raton, FL, USA, 2006; pp. 397-443.

146. Regnault-Roger, C.; Vincent, C.; Arnason, J.T. Essential oils in insect control: Low-risk products in a high-stakes world. Annu. Rev. Entomol. 2012, 57, 405-424. [CrossRef]

147. Silva, V.C.B.; Ribeiro Neto, J.A.; Alves, S.N.; Li, L.A.R.S. Larvicidal activity of oils, fatty acids, and methyl esters from ripe and unripe fruit of Solanum lycocarpum (Solanaceae) against the vector Culex quinquefasciatus (Diptera: Culicidae). Rev. Soc. Bras. Med. 2015, 48, 610-613. [CrossRef]

148. Velu, K.; Elumalai, D.; Hemalatha, P.; Babu, M.; Janaki, A.; Kaleena, P.K. Phytochemical screening and larvicidal activity of peel extracts of Arachis hypogaea against chikungunya and malarial vectors. Int. J. Mosq. Res. 2015, 2, 01-08.

149. Rajashekar, Y.; Bakthavatsalam, N.; Shivanandappa, T. Botanicals as grain protectants. Psyche 2012, 2012, 646740. [CrossRef]

150. Kona, N.E.M.; Taha, A.K.; Mahmoud, M.E.E. Effects of botanical extracts of Neem (Azadirachta indica) and jatropha (Jatropha curcus) on eggs and larvae of tomato leaf miner, Tuta absoluta (Meyrick) (Lepidoptera: Gelechiidae). Persian Gulf Crop Prot. 2014, 3, 41-46.

151. Abdel-Baky, N.F.; Al-Soqeer, A.A. Controlling the2nd instar larvae of Tuta absoluta Meyrick (Lepidoptera: Gelechiidae) by Simmondsin extracted from Jojoba seeds in KSA. J. Entomol. 2017, 14, 73-80.

152. Shiberu, T.; Getu, E. Evaluation of Bio-Pesticides on Integrated Management of Tomato Leafminer, Tuta absoluta (Meyrick) (Gelechiidae: Lepidoptera) on Tomato Crops in Western Shewa of Central Ethiopia. Entomol. Ornithol. Herpetol. 2018, 7, 206. [CrossRef]

153. De Brito, E.F.; Baldin, E.L.L.; de Carvalho Macedo Silva, R.; do Prado Ribeiro, L.; Vendramim, J.D. Bioactivity of Piper extracts on Tuta absoluta (Lepidoptera: Gelechiidae) in tomato. Pesq. Agropec. Bras. Brasilia. 2015, 50, 196-202. [CrossRef] 
154. Dyer, L.A.; Palmer, A.N.D. Piper: A Model Genus for Studies of Phytochemistry, Ecology and Evolution; Kluwer Academic/Plenum Publishers: New York, NY, USA, 2004; p. 228.

155. Scott, I.M.; Helson, B.V.; Strunz, G.M.; Finlay, H.; Sanchez-Vindas, P.E.; Poveda, L.; Lyons, D.B.; Philogene, B.J.R.; Arnason, J.T. Efficacy of Piper nigrum (Piperaceae) extract for control of insect defoliators of forest and ornamental trees. Can. Entomol. 2007, 139, 513-522. [CrossRef]

156. Abd El-Ghany, N.M.; Abdel-Razek, A.S.; Ebadah, I.M.A.; Mahmoud, Y.A. Evaluation of some microbial agents, natural and chemical compounds for controlling tomato leaf miner, Tuta absoluta (Meyrick) (Lepidoptera: Gelechiidae). J. Plant Prot. Res. 2016, 56, 372-379. [CrossRef]

157. Birhan, A. Tomato leafminer [(Tuta absoluta Meyrick) (Lepidoptera: Gelechiidae)] and its current ecofriendly management strategies: A review. J. Agric. Biotech. Sustain. Dev. 2018, 10, 11-24. [CrossRef]

158. Zarrad, K.; Chaieb, I.; Tayeb, W.; Chraief, I.; Laarif, A.; Hammami, M.; Haouala, R. Bio-insecticidal potential of essential oils of two citrus species against two greenhouse pests Tuta absoluta Meyrick and Spodoptera littoralis Boisduval. Microbiologie et Hygiène Alimentaire 2013, 25, 84-88.

159. Rodriguez, S.M.; Gerding, P.; France, A. Seleccio'n de aislamientos de hongos entomopato'genos para el control de huevos de la polilla del tomate, Tuta absoluta (Meyrick) (Lepidoptera: Gelechiidae). Agric. Technol. 2005, 66, 151-158.

160. Gonzalez-Cabrera, J.; Molla, O.; Monton, H.; Urbaneja, A. Efficacy of Bacillus thuringiensis (Berliner) in controlling the tomato borer, Tuta absoluta (Meyrick) (Lepidoptera: Gelechiidae). BioControl 2011, 56, 71-80. [CrossRef]

161. Youssef, N.A.; Hassan, G.M. Bioinsecticide activity of Bacillus thuringiensis isolates on tomato borer, Tuta absoluta (Meyrick) and their molecular identification. Afr. J. Biotechnol. 2013, 12, 3699-3709.

162. Jacobson, R.J.; Chandler, D.; Fenlon, J.; Russell, K.M. Compatibility of Beauveria bassiana (Balsamo) Vuillemin with Amblyseius cucumeris Oudemans (Acarina: Phytoseiidae) to control Frankliniella occidentalis Pergande (Thysanoptera: Thripidae) on cucumber plants. Biocontrol Sci. Technol. 2001, 11, 391-400. [CrossRef]

163. Mburu, D.M.; Ochola, N.K.; Maniania, P.G.N.; Gitonga, L.M.; Ndung'u, M.W.; Wanjoya, A.K.; Hassanali, A. Relationship between virulence and repellency of entomopathogenic isolates of Metarhizium anisopliae and Beauveria bassiana to the termite Macrotermes michaelseni. J. Insect Physiol. 2009, 55, 774-780. [CrossRef] [PubMed]

164. Alsaedi, G.; Ashouri, A.; Talaei-Hassanloui, R. Evaluation of Bacillus thuringiensis to control Tuta absoluta (Meyrick) (Lepidoptera: Gelechiidae) under laboratory conditions. Agric. Sci. 2017, 8, 591-599. [CrossRef]

165. Racke, K.D. A Reduced Risk Insecticide for Organic Agriculture: Spinosad Case Study. In Crop Prot. Products for Organic Agriculture: Environmental, Health and Efficacy Assessment; Felsot, A.S., Racke, K.D., Eds.; ACS: Washington, DC, USA, 2006; pp. 92-108.

166. Baniameri, V.; Cheraghian, A. The first report and control strategies of Tuta absoluta in Iran. EPPO Bull. 2012, 2, 322-324. [CrossRef]

167. Biondi, A.; Zappalá, L.; Stark, J.D.; Desneux, N. Do biopesticides affect the demographic traits of a parasitoid wasp and its biocontrol services through sublethal effects? PLoS ONE 2013, 8, e76548. [CrossRef]

168. Caparros Megido, R.; Haubruge, E.; Verheggen, F.J. First evidence of deuterotokous parthenogenesis in the tomato leafminer, Tuta absoluta (Meyrick) (Lepidoptera: Gelechiidae). J. Pest Sci. 2012, 85, 409-412. [CrossRef]

169. CABI. 2013. Available online: https://www.cabi.org/isc/datasheet/49260\#tonaturalEnemies (accessed on 7 April 2020).

170. Contreras, J.; Mendoza, J.E.; Martínez-Aguirre, M.R.; García-Vidal, L.; Izquierdo, J.; Bielza, P. Efficacy of entomopathogenic fungus Metarhizium anisopliae against Tuta absoluta (Lepidoptera: Gelechiidae). J. Econ. Entomol. 2014, 107, 121-124. [CrossRef]

171. Gomez, J.; Barrera, G.; Lopez-Feeber, M.; Belaich, M.; Ghiringhelli, P.; Villamizar, L.F. Potential for betabaculoviruses to the control of tomato leafminer Tuta absoluta (Meyrick). J. Appl. Entomol. 2017, 142, 67-77. [CrossRef]

172. Gozel, C.; Kasap, I. Efficacy of entomopathogenic nematodes against the Tomato leafminer, Tuta absoluta (Meyrick) (Lepidoptera: Gelechiidae) in tomato field. Turk. Entomol. Derg-Tu. 2015, 39. [CrossRef]

173. Broekaert, W.F.; Cammue, B.P.A.; De Bolle, M.F.C.; Thevissen, K.; De Samblanx, G.W.; Osborn, R.W. Antimicrobial peptides from plants. Crit. Rev. Plant Sci. 1997, 16, 297-323. [CrossRef]

174. Adams, B.J.; Nguyen, K.B. Taxonomy and Systematics, in Entomopathogenic Nematology; Gaugler, R., Ed.; CABI: New York, NY, USA, 2002; pp. 1-34. 
175. Boemare, N. Biology, Taxonomy and Systematics of Photorhabdus and Xenorhabdus. In Entomopathogenic Nematology; Gaugler, R., Ed.; CABI: New York, NY, USA, 2002; pp. 35-56.

176. De Waal, J.Y.; Malan, A.P.; Addison, M.F. Efficacy of entomopathogenic nematodes (Rhabditida: Heterorhabditidae and Steinernematidae) against codling moth, Cydia pomonella (Lepidoptera: Tortricidae) in temperate regions. Biocontrol Sci. Technol. 2011, 21, 1161-1176. [CrossRef]

177. Van Damme, V.M.; Beck, B.K.; Berckmoes, E.; Moerkens, R.; Wittemans, L.; de Vis, R.; Nuyttens, D.; Casteels, H.F.; Maes, M.; Tirry, L.; et al. Efficacy of entomopathogenic nematodes against larvae of Tuta absoluta in the laboratory. Pest Manag. Sci. 2015, 72, 1702-1709. [CrossRef] [PubMed]

178. Malan, A.P.; Knoetze, R.; Moore, S.D. Isolation and identification of entomopathogenic nematodes from citrus orchards in South Africa and their biocontrol potential against false codling moth. J. Invertebr. Pathol. 2011, 108, 115-125. [CrossRef]

179. Nthenga, I.; Knoetze, R.; Berry, S.; Tiedt, L.R.; Malan, A.P. Steinernema sacchari n. sp. (Rhabditida: Steinernematidae), a new entomopathogenic nematode from South Africa. Nematology 2014, 16, 475-494. [CrossRef]

180. Caparros Megido, R.; Haubruge, E.; Verheggen, F.J. Pheromone-based management strategies to control the tomato leafminer, Tuta absoluta (Lepidoptera: Gelechiidae). A review. Biotechnol. Agron. Soc. Environ. 2013, 17, 475-482.

181. Mashaly, A.; Ali, M.; Al-Khalifa, M. Trail Pheromones in Pest Control. In New Perspectives in Plant Protection; IntechOpen: London, UK, 2012. [CrossRef]

182. Filho, M.M.; Vilelaa, E.F.; Jham, G.N.; Attygalle, A.; Svatos, A.; Meinwald, J. Initial studies of mating disruption of the tomato moth, Tuta absoluta (Lepidoptera: Gelechiidae) using synthetic sex pheromone. J. Braz. Chem. Soc. 2000, 6, 621-628. [CrossRef]

183. El-aassar, M.R.; Soliman, M.H.A.; Elaal, A.A.A. Efficiency of sex pheromone traps and some bio and chemical insecticides against tomato borer larvae, Tuta absoluta (Meyrick) and estimate the damages of leaves and fruit tomato plant. Ann Agric Sci. 2015, 60, 153-156. [CrossRef]

184. Cherif, A.; Harbaoui, K.; Zappalà, L.; Grissa-Lebdi, K. Efficacy of mass trapping and insecticides to control Tuta absoluta in Tunisia. J. Plant Dis. Protect. 2018, 125, 51-61. [CrossRef]

185. Cook, S.M.; Khan, Z.R.; Pickett, J.A. The Use of Push-Pull Strategies in Integrated Pest Management. Annu. Rev. Entomol. 2007, 52, 375-400. [CrossRef] [PubMed]

186. Dyck, V.A.; Hendrichs, J.; Robinson, A.S. Sterile Insect Technique: Principles and Practice in Area-Wide Integrated Pest Management; Springer: Dordrecht, The Netherlands, 2005.

187. Knipling, E.F. Possibilities of insect control or eradication through the use of sexually sterile males. J. Econ. Entomol. 1955, 48, 459-467. [CrossRef]

188. Carabajal Paladino, L.Z.; Ferrari, M.E.; Lauría, J.P.; Cagnotti, C.L.; Šíchová, J.; López, S.N. The Effect of X-Rays on Cytological Traits of Tuta absoluta (Lepidoptera: Gelechiidae). Fla. Entomol. 2016, 99, 43-53. [CrossRef]

189. Suckling, D.M.; Stringer, L.D.; Mitchell, V.J.; Sullivan, T.E.S.; Sullivan, N.J.; Simmons, G.S.; Barrington, A.M.; El-Sayed, A.M. Comparative fitness of irradiated sterile light brown apple moths (Lepidoptera: Tortricidae) in a wind tunnel, hedgerow and vineyard. J. Econ. Entomol. 2011, 104, 1301-1308. [CrossRef] [PubMed]

190. Chidawanyika, F.; Terblanche, J.S. Costs and benefits of thermal acclimation for codling moth, Cydia pomonella (Lepidoptera: Tortricidae): Implications for pest control and the sterile insect release programme. Evol. Appl. 2011, 4, 534-544. [CrossRef] [PubMed]

191. Cagnotti, C.L.; Andorno, A.V.; Hernández, C.M.; Carabajal Paladino, L.Z.; Botto, E.; López, S. Inherited Sterility in Tuta absoluta (Lepidoptera: Gelechiidae): Pest Population Suppression and Potential for Combined Use with a Generalist Predator. Fla. Entomol. 2016, 99, 87-94. [CrossRef]

192. Nepgen, E.S. A Study on the Application Technology of the Sterile Insect Technique, with Focus on False Codling Moth, Thaumatotibia leucotreta (Meyrick) (Lepidoptera: Tortricidae), a Pest of Citrus in South Africa. Master's Thesis, Rhodes University, Grahamstown, South Africa, 2014; p. 106.

193. Bloem, K.A.; Bloem, S.; Carpenter, J.E. Impact of Moth Suppression/eradication Programmes Using the Sterile Insect Technique or Inherited Sterility. In Sterile Insect Technique. Principles and Practice in Area-Wide Integrated Pest Management; Dyck, V.A., Hendrichs, J., Robinson, A.S., Eds.; Springer: Dordrecht, The Netherlands, 2005; pp. 677-700. 
194. Carpenter, J.E. Area-wide Integration of Lepidopteran $F_{1}$ Sterility and Augmentative Biological Control. In Area-Wide Control of Fruit Flies and Other Insect Pests, Proceedings of the International Conference on Area-Wide Control of Insect Pests, and the 5th International Symposium on Fruit Flies of Economic Importance, Penang, Malaysia, 28 May-5 June 1998; Tan, K.H., Ed.; Penerbit Universiti Sains Malaysia: Pulau Pinang, Malaysia, 2000; pp. 193-200.

195. Dyck, V.A.; Reyes Flores, J.; Vreysen, M.J.B.; Regidor, E.E.; Barnes, T.T.B.; Riera, P.G.; Lindquist, D.; Loosjes, M. Management of Area-wide Integrated Pest Management Programmes that Integrate the Sterile Insect Technique. In Sterile Insect Technique. Principles and Practice in Area-Wide Integrated Pest Management; Dyck, V.A., Hendrichs, J., Robinson, A.S., Eds.; Springer: Dordrecht, The Netherlands, 2005; pp. 525-538.

196. Giustolin, T.A.; Vendramim, J.D.; Alves, S.B.; Vieira, S.A.; Pereira, R.M. Susceptibility of Tuta absoluta (Meyrick) (Lepidoptera, Gelechiidae) reared on two species of Lycopersicon to Bacillus thuringiensis var. kurstaki. J. Appl. Entomol. 2001, 125, 551-556. [CrossRef]

197. Gharekhani, G.H.; Salek-Ebrahimi, H. Evaluating the damage of Tuta absoluta (Meyrick) (Lepidoptera: Gelechiidae) on some cultivars of tomato under greenhouse condition. Arch. Phytopathol. Pflanzenschutz. 2014, 47, 429-436. [CrossRef]

198. Han, P.; Bayram, Y.; Shaltiel-Harpaz, L.; Sohrabi, F.; Saji, A.; Esenali, U.T.; Jalilov, A.; Ali, A.; Shashank, P.R.; Ismoilov, K.; et al. Tuta absoluta continues to disperse in Asia: Damage, ongoing management and future challenges. J. Pest Sci. 2019, 92, 1317-1327. [CrossRef]

199. Fernandes, M.E.F.; Fernandes, F.L.; Silva, D.J.H.; Picanço, M.; Jhamc, G.N.; Carneiro, P.; Queiroz, R.B. Trichomes and hydrocarbons associated with the tomato plant antixenosis to the leafminer. An. Acad. Bras. Ciências 2012, 84, 201-210. [CrossRef]

200. Oliveira, F.A.; da Silva, D.J.H.; Leite, G.L.D.; Jham, G.N.; PicançO, M. Resistance of 57 greenhouse-grown accessions of Lycopersicon esculentum and three cultivars to Tuta absoluta (Meyrick) (Lepidoptera: Gelechiidae). Sci. Hortic. 2009, 119, 182-187. [CrossRef]

201. De Oliveira, C.M.; de Andrade, V.C., Jr.; Maluf, W.R.; Neiva, I.P.; Maciel, G.M. Resistance of tomato strains to the moth Tuta absoluta imparted by allelochemicals and trichome density. Ciênc. Agrotec. 2012, 36, 45-52. [CrossRef]

202. Sohrabi, F.; Nooryazdan, H.R.; Gharati, B.; Saeidi, Z. Plant resistance to the moth Tuta absoluta (Meyrick) (Lepidoptera: Gelechiidae) in tomato cultivars. Neotrop. Entomol. 2016, 46, 203-209. [CrossRef] [PubMed]

203. Ghaderi, S.; Fathipour, Y.; Asgari, S. Susceptibility of seven selected tomato cultivars to Tuta absoluta (Lepidoptera: Gelechiidae): Implications for its management. J. Econ. Entomol. 2017, 110, 421-429. [CrossRef] [PubMed]

204. Proffit, M.; Birgersson, G.; Bengtsson, M.; Reis, R.; Witzgall, P.; Lima, E. Attraction and oviposition of Tuta absoluta females in response to tomato leaf volatiles. J. Chem. Ecol. 2011, 37, 565-574. [CrossRef] [PubMed]

205. Kant, M.R.; Ament, K.; Sabelis, M.W.; Harin, M.A.; Schuurink, R.C. Differential timing of spider mite-induced direct and indirect defences in tomato plants. Plant Physiol. 2004, 135, 483-495. [CrossRef] [PubMed]

206. Urbaneja, A.; González-Cabrera, J.; Arnó, J.; Gabarra, R. Prospects for the biological control of Tuta absoluta in tomatoes of the Mediterranean basin. Pest Manag. Sci. 2012, 68, 1215-1222. [CrossRef]

207. Luna, M.G.; Pereyra, P.C.; Coviella, C.E.; Junior, R.R.; Witzgall, P.; Lim, E. Potential of Biological Control agents against Tuta absoluta (Lepidoptera: Gelechiidae): Current knowledge in Argentina. Fla. Entomol. 2015, 98, 565-574. [CrossRef]

208. Jaworski, C.C.; Chailleux, A.; Bearez, P.; Desneux, N. Apparent competition between major pests reduces pest population densities on tomato crop, but not yield loss. J. Pest Sci. 2015, 88, 793-803. [CrossRef]

209. Mollá, O.; González-Cabrera, J.; Urbaneja, A. The combined use of Bacillus thuringiensis and Nesidiocoris tenuis against the tomato borer Tuta absoluta. Biol. Control 2011, 56, 883-891. [CrossRef]

210. Arnó, J.; Sorribas, R.; Prat, M.; Matas, M.; Pozo, C.; Rodríguez, D.; Garreta, A.; Gómez, A.; Gabarra, R. Tuta absoluta, a new pest in IPM tomatoes in the northeast of Spain. IOBC/WPRS Bull. 2009, 49, 203-208.

211. Parra, J.R.P.; Zucchi, R.A. Trichogramma in Brazil: Feasibility of use after twenty years of research. Neotrop. Entomol. 2004, 33, 271-281. [CrossRef]

212. Chailleux, A.; Desneux, N.; Seguret, J.; Do Thi Khanh, H.; Maignet, P.; Tabone, E. Assessing European Egg Parasitoids as a Mean of Controlling the Invasive South American Tomato Pinworm Tuta absoluta. PLoS ONE 2012, 7, e48068. [CrossRef] 
213. Pratissoli, D.; Thuler, R.T.; Andrade, G.S.; Zanotti, L.C.M.; da Silva, A.F. Estimate of Trichogramma pretiosum to control Tuta absoluta in stalked tomato. Pesqui. Agropecu. Bras. 2005, 40,715-718. [CrossRef]

214. Cabello, T.; Gallego, J.R.; Fernandez, F.J.; Gamez, M.; Vila, E.; Del Pino, M.; Hernandez-Suarez, E. Biological Control strategies for the South American tomato moth (Lepidoptera: Gelechiidae) in greenhouse tomatoes. J. Econ. Entomol. 2012, 105, 2085-2096. [CrossRef] [PubMed]

215. Mansour, R.; Cherif, A.; Attia-Barhoumi, S.; Zappalà, L.; Grissa-Lebdi, K. Tuta absoluta in Tunisia: Ten years of invasion and pest management. Phytoparasitica 2019, 47, 461-474. [CrossRef]

216. Colomo, M.V.; Berta, D.C.; Chocobar, M.J. El complejo de himenópteros parasitoides que atacan a la "polilla del tomate" Tuta absoluta (Lepidoptera: Gelechiidae) en la Argentina. Acta Zool. Lilloana. 2002, 46, 81-92.

217. Luna, M.G.; Sánchez, N.E.; Pereyra, P.C. Parasitism of Tuta absoluta (Lepidoptera: Gelechiidae) by Pseudapanteles dignus (Hymenoptera: Braconidae) under laboratory conditions. Environ. Entomol. 2007, 36, 887-893. [CrossRef]

218. Mollá, O.; Monton, H.; Beitia Crespo, F.J.; Urbaneja, A. La polilla del tomate Tuta absoluta (Meyrick), una nueva plaga invasora. Terralia 2008, 69, 36-42.

219. Marchiori, C.H.; Silva, C.G.; Lobo, A.P. Parasitoids of Tuta absoluta (Meyrick, 1917) (Lepidoptera: Gelechiidae) collected on tomato plants in larvae, State of Minas Gerais, Brazil. Braz. J. Biol. 2004, 64, 551-552. [CrossRef]

220. Doğanlar, M.; Yiğit, A. Parasitoid complex of the tomato leaf miner, Tuta absoluta (Meyrick 1917), (Lepidoptera: Gelechiidae) in Hatay, Turkey. Tarim ve Doga Dergisi. 2011, 14, $28-37$.

221. Gabarra, R.; Arnó, J. Resultados de las experiencias de control biológico de la polilla del tomate en cultivo de invernadero y aire libre en Cataluña. Phytoma España. 2010, 217, 65-68.

222. Zappalá, L.; Bernardo, U.; Biondi, A.; Cocco, A.; Deliperi, S.; Delrio, G.; Giorgini, M.; Pedata, P.C.; Rapisarda, C.; Tropea Garzia, G.; et al. Recruitment of native parasitoids by the exotic pest Tuta absoluta (Meyrick) in Southern Italy. Bull. Insectology 2012, 65, 51-61.

223. Cáceres, S.; Aguirre, A.; Miño, V.; Almonacid, R. Líneas de trabajo para el manejo integrado de la polilla del tomate en Corrientes. Libro de Resúmenes del Taller: La polilla del tomate en la Argentina: Estado actual del conocimiento y prospectiva para un manejo integrado de plagas; Facultad De Ciencias Naturales Museo, Univesidad Nacional De La Plata: Buenes Aires, Argentina, 2011; p. 7.

224. Biondi, A.; Chailleux, A.; Lambion, J.; Zappalá, L.; Desneux, N. Indigenous natural enemies attacking Tuta absoluta (Lepidoptera: Gelechiidae) in Southern France. Egypt J. Biol. Pest Control 2013, 23, 117-121.

225. Gabarra, R.; Arnó, J.; Lara, L.; Verdú, M.J.; Ribes, A.; Beitia, F.; Urbaneja, A.; Téllez, M.M.; Mollá, O.; Riudavets, J. Native parasitoids associated with Tuta absoluta in the tomato production areas of the Spanish Mediterranean Coast. Biocontrol 2013. [CrossRef]

226. Boualem, M.; Allaoui, H.; Hamadi, R.; Medjahed, M. Biologie et complexe des ennemis naturels de Tuta absoluta á Mostaganem (Algérie). EPPO Bull. 2012, 42, 268-274. [CrossRef]

227. Riciputi, C. Pomodoro, contro la Tuta tre nuovi predatori naturali. Colt. Protette. 2011, 40, 32-34.

228. Zouba, A.; Chermiti, B.; Kadri, K.; Fattouch, S. Molecular characterization of Trichogramma bourarachae strains (Hymenoptera: Trichogrammatidae) from open field tomato crops in the South West of Tunisia. Biomirror 2013, 4, 13-19.

229. Mollá, O.; Alonso, M.; Monton, H.; Beitia, F.; Verdú, M.J.; González-Cabrera, J.; Urbaneja, A. Control Biologico de Tuta absoluta. Catalogacion de enemigos naturales y potencial de los miridos depredadores como agentes de control. Phytoma Spain 2010, 217, 42-46.

230. Ferracini, C.; Ingegno, B.L.; Mosti, M.; Navone, P.; Tavella, L.; Alma, A. Promising native candidates for biological control of Tuta absoluta in Italy. IOBC/WPRS Bull. 2012, 80, 51-55.

231. Pérez-Aguilar, D.A.; Soares, M.A.; Passos, L.C.; Martínez, A.M.; Pineda, S.; Carvalho, G.A. Lethal and sublethal effects of insecticides on Engytatus varians (Heteroptera: Miridae), a predator of Tuta absoluta (Lepidoptera: Gelechiidae). Ecotoxicology 2018, 27, 719-728. [CrossRef] [PubMed]

232. Cabello, T.; Gallego, J.R.; Fernandez-Maldonado, F.J.; Soler, A.; Beltran, D.; Parra, A.; Vila, E. The damsel bug Nabis pseudoferus (Hem.: Nabidae) as a new biological control agent of the South American Tomato Pinworm, Tuta absoluta (Lep.: Gelechiidae), in tomato crops of Spain. IOBC/WPRS Bull. 2009, 49, 219-223.

233. Al-Jboory, I.J.; Katbeh-Bader, A.; Al-Zaidi, S. First observation and identification of some natural enemies collected from heavily infested tomato by Tuta absoluta (Meyrick) (Lepidoptera: Gelechiidae) in Jordan. Middle East J. Sci. Res. 2012, 11, 435-438. 
234. Braham, M.; Hajji, L. Management of Tuta absoluta (Lepidoptera, Gelechiidae) with Insecticides on Tomatoes; Insecticides.-Pest Engineering; Perveen, F., Ed.; InTech: Rijeka, Croitia, 2012; pp. 1-23, ISBN 978-953-307-895-3.

235. Radwan, E.; Taha, H. Toxic and biochemical effects of different insecticides on the tomato leafminer, Tuta absoluta (Meyrick) (Lepidoptera: Gelechiidae). Egypt Acad. J. Biol. Sci. 2012, 4, 1-10. [CrossRef]

236. Deleva, E.A.; Harizanova, V.B. Efficacy Evaluation of Insecticides on Larvae of the Tomato Borer Tuta absoluta, Meyrick (Lepidoptera: Gelechiidae) under Laboratory Conditions. J. Int. Sci. Publ. Agric. Food. 2014, 2. Available online: http://www.scientificpublications.net (accessed on 13 May 2020).

237. Lu, Y.; Wu, K.; Jiang, Y.; Guo, Y.; Desneux, N. Widespread adoption of Bt cotton and insecticide decrease promotes biocontrol services. Nature 2012, 487, 362-365. [CrossRef] [PubMed]

238. Smith, C.M. Plant Resistance to Arthropods: Molecular and Conventional Approaches; Springer: Dordrecht, The Netherlands, 2005.

239. Fusire, M. Integrated Pest Management: Cost-Saving Techniques for Small Holder Farmers; Community Technology Development Trust: Harare, Zimbabwe, 2008.

240. Bale, J.S. Harmonization of regulations for invertebrate biocontrol agents in Europe: Progress, problems and solutions. J. Appl. Entomol. 2011, 135, 503-513. [CrossRef]

241. Cherry, A.J.; Gwynn, R.L. Perspectives on the development of Biological Control agents in Africa. Biocontrol Sci. Technol. 2007, 17, 665-676. [CrossRef]

242. van Lenteren, J.C. The state of commercial augmentative biological control: Plenty of natural enemies, but a frustrating lack of uptake. Biol. Control 2012, 57, 1-20. [CrossRef]

243. Mason, P.J.; Everatt, M.J.; Loomans, A.J.M.; Collatz, J. Harmonizing the regulation of invertebrate biological control agents in the EPPO region: Using the NAPPO region as a model. Bull. OEPP/EPPO 2017, 47, 79-90. [CrossRef]

244. Benjamin, E.O.; Wesseler, J.H.H. A socioeconomic analysis of biocontrol in integrated pest management: A review of the effects of uncertainty, irreversibility and flexibility. NJAS_Wagen. J. Life Sci. 2016, 77, 53-60. [CrossRef]

245. Gwynn, R.; Maniania, J.K. Africa with special reference to Kenya. In Use and Regulation of Microbial Pesticides in Representative Jurisdictions Worldwide; Kabuluk, T., Svircev, A., Goettel, M., Woo, S.G., Eds.; IOBC Global: St. Paul, MN, USA, 2010; pp. 12-17.

246. Grzywacz, D.; Stevenson, P.C.; Mushobozi, W.L.; Belmain, S.; Wilson, K. The use of indigenous ecological resources for pest control in Africa. Food Secur. 2014, 6, 71-86. [CrossRef]

247. Sola, P.; Mvumi, B.M.; Ogendo, J.O.; Mponda, O.; Kamanula, J.F.; Nyirenda, S.P.; Belmain, S.R.; Stevenson, P.C. Botanical pesticide production, trade and regulatory mechanisms in sub-Saharan Africa: Making a case for plant based pesticidal products. Food Secur. 2014, 6, 369-384. [CrossRef]

248. Naranjo, S.E.; Ellsworth, P.C.; Frisvold, G.B. Economic Value of Biological Control in Integrated Pest Management of Managed Plant Systems. Annu. Rev. Entomol. 2015, 60, 621-645. [CrossRef] [PubMed]

249. Amoabeng, B.W.; Gurr, G.M.; Gitau, C.W.; Stevenson, P.C. Cost: Benefit analysis of botanical insecticide use in cabbage: Implications for smallholder farmers in developing countries. Crop Prot. 2014, 57, 71-76. [CrossRef]

250. Belmain, S.; Stevenson, P. Ethnobotanicals in Ghana: Reviving and Modernizing Age-Old Farmer, Practice. Pestic. Outlook 2001, 12, 233-238.

251. Food and Agriculture Organization of the United Nations (FAO); World Health Organization (WHO). International Code of Conduct on Pesticide Management: Guidelines for the Registration of Microbial, Botanical and Semiochemical Pest Control Agents for Plant Protection and Public Health Uses. Rome, Italy. 2017. Available online: www.fao.org/publications (accessed on 23 April 2020).

252. Carvalho, F.P. Pesticides, environment, and food safety. Food Energy Secur. 2017, 6, 48-60. [CrossRef]

253. Thompson, L.A.; Darwish, W.S. Environmental Chemical Contaminants in Food: Review of a Global Problem. J. Toxicol. 2019, 2345283. [CrossRef]

254. Cannell, E. European farmers plough ahead: Pesticide use reduction. Pestic. News 2007, 78. Available online: http://www.pan-Europe.info (accessed on 16 March 2011).

255. De Groote, H.; Douro-Kpindou, O.K.; Ouambama, Z.; Gbongboui, C.; Müller, D.; Attignon, S.; Lomer, C. Assessing the feasibility of biological control of locusts and grasshoppers in West Africa: Incorporating the farmers' perspective. Agric. Hum. Values 2001, 18, 413-428. [CrossRef] 
256. Jussaume, R.A.; Glenna, L. Considering structural, individual and social network explanations for ecologically sustainable agriculture: An example drawn from Washington State wheat growers. Sustainability 2009, 1, 120-132. [CrossRef]

257. Grogan, K.A. When ignorance is bliss: Pest control decisions involving beneficial insects. Ecol. Econ. 2014, 107, 104-113. [CrossRef]

258. Wyckhuys, K.A.G.; Heong, K.L.; Sanchez-Bayo, F.; Bianchi, F.J.J.A.; Lundgren, J.G.; Bentley, J.W. Ecological illiteracy can deepen farmers' pesticide dependency. Environ. Res. Lett. 2019, 14, 093004. [CrossRef]

259. Grzywacz, D.; Cherry, A.C.; Gwynn, R. Biological pesticides for Africa: Why has so little of the research undertaken to date led to new products to help Africa's poor? Pestic. Outlook 2009, 20, 77-81. [CrossRef]

260. Leng, P.; Zhang, Z.; Pan, G.; Zhao, M. Applications and development trends in biopesticides. Afr. J. Biotechnol. 2011, 10, 19864-19873.

261. McConnachie, A.J.; de Wit, M.P.; Hill, M.P.; Byrne, M.J. Economic evaluation of the successful biological control of Azolla filiculoides in South Africa. Biol. Control 2003, 28, 25-32. [CrossRef]

262. TEEB (The Economics of Ecosystems and Biodiversity). Ecological and Economic Foundation; Earthscan: Cambridge, UK, 2020.

263. Pimentel, D. Environmental and Economic Costs of the Application of Pesticides Primarily in the United States. In Integrated Pest Management: Innovation-Development Process; Peshin, R., Dhawan, A.K., Eds.; Springer: Dordrecht, The Netherlands, 2009.

264. Rahaman, P.F.; Sharma, S.B.; Wightman, J.A. A review of insect parasitic nematodes research in India: 1927-1997. Int. J. Pest Manag. 2000, 46, 19-28. [CrossRef]

265. Lacey, L.A.; Georgis, R. Entomopathogenic Nematodes for Control of Insect Pests Above and Below Ground with Comments on Commercial Production. J. Nematol. 2012, 44, 218-225.

266. Knox, C.; Moore, S.D.; Luke, G.A.; Hill, M.P. Baculovirus-based strategies for the management of insect pests: A focus on development and application in South Africa. Biocontrol Sci. Technol. 2015, 25, 1-20. [CrossRef]

267. Copping, L.G.; Menn, J.J. Biopesticides: A review of their action, applications and efficacy. Pest Manag. Sci. 2000, 56, 651-676. [CrossRef]

268. Barratt, B.I.P.; Moran, V.C.; Bigler, F.; van Lenteren, J.C. The status of Biological Control and recommendations for improving uptake for the future. Biol. Control 2018, 63, 155-167. [CrossRef]

269. Pimentel, D.; Goodman, N. Ecological basis for the management of insect populations. OIKOS 1978, 30, 422-437. [CrossRef]

270. Tena, A.; Wäckers, F.L.; Heimpel, G.E.; Urbaneja, A.; Pekas, A. Parasitoid nutritional ecology in a community context: The importance of honeydew and implications for biological control. Curr. Opin. Insect Sci. 2016, 14, 100-104. [CrossRef] [PubMed]

271. Chidawanyika, F.; Mudavanhu, P.; Nyamukondiwa, C. Global Climate Change as a Driver of Bottom-Up and Top-Down Factors in Agricultural Landscapes and the Fate of Host-Parasitoid Interactions. Front. Ecol. Evol. 2019, 7, 80. [CrossRef]

272. Bélair, G.; Fournier, Y.; Dauphinais, N. Efficacy of steinernematid nematodes against three insect pests of crucifers in Quebec. J. Nematol. 2003, 35, 259-265.

273. Muniappan, R.; Bamba, J. Biological control of Chromolaena odorata: Successes and Failures. In Proceedings of the X International Symposium on Biological Control of Weeds, 4-14 July 1999; Spencer, N.R., Ed.; Montana State University: Bozeman, MT, USA, 2000; pp. 151-154.

274. Myers, J.H. What Can We Learn from biological control Failures? In Proceedings of the $X$ International Symposium on Biological Control of Weeds, Bozeman, MT, USA, 4-14 July 1999; Spencer, N.R., Ed.; Montana State University: Bozeman, MT, USA, 2000; pp. 81-85.

275. Georgis, R.; Koppenhöfer, A.M.; Lacey, L.A.; Bélair, G.; Duncan, L.W.; Grewal, P.S.; Samish, M.; Tan, L.; Torr, P.; van Tol, R.W.H.M. Successes and failures in the use of parasitic nematodes for pest control. Biol. Control 2006, 38, 103-123. [CrossRef]

276. Ngowi, A.V.F.; Mbise, T.J.; Ijani, A.S.M.; London, L.; Ajayi, O.C. Knowledge, attitudes and practices (KAP) among agricultural extension workers concerning the reduction of the adverse impact in agricultural areas in Tanzania. Crop Prot. 2007, 26, 1617-1624. [CrossRef]

277. Goldberger, J.R.; Lehrer, N. Biological control adoption in western U.S. orchard systems: Results from grower surveys. Biol. Control 2016, 102, 101-111. [CrossRef] 
278. Obopile, M.; Munthali, D.C.; Matilo, B. Farmers' knowledge, perceptions and management of vegetable pests and diseases in Botswana. Crop Prot. 2008, 27, 1220-1224. [CrossRef]

279. Wyckhuys, K.A.G.; Hughes, A.C.; Buamas, C.; Johnson, A.C.; Vasseur, L.; Raymondin, L.; Deguine, J.P.; Sheil, D. Biological control of an agricultural pest protects tropical forests. Commun. Biol. 2019. [CrossRef]

(C) 2020 by the authors. Licensee MDPI, Basel, Switzerland. This article is an open access article distributed under the terms and conditions of the Creative Commons Attribution (CC BY) license (http://creativecommons.org/licenses/by/4.0/). 